\title{
English Prisons, Penal Culture, and the Abatement of Imprisonment, 1895-1922
}

\author{
Victor Bailey
}

The prison method is callous, regular and monotonous and produces great mental and physical strain. The deprivation of liberty is extremely cruel and if it is attended with treatment that deadens the spiritual nature and fails to offer any stimulus to the imagination, that coarsens and humiliates, then it stands condemned. (Arthur Creech Jones, conscientious objector, Wandsworth Prison, $1916-19)^{1}$

\section{I}

The nineteenth century was the century of the penitentiary. Public and physical punishments (from whipping to the death penalty) were gradually replaced by the less visible, less corporal sanction of imprisonment. By the start of the Victorian era, imprisonment was the predominant penalty in the system of judicial punishments. For every 1,000 offenders sentenced at higher and summary courts in 1836 for serious (or indictable) offenses, 685 were punished by imprisonment in local prisons. ${ }^{2}$ By midcentury, moreover, sentences of penal servitude in convict

VICTOR BAILEY is grateful to the University of Kansas for a General Research Fund award which made it possible to complete this article. He would also like to thank John Beattie, Joanna Innes, Randall McGowen, Elaine Reynolds, Nancy Scott, and Martin Wiener for their valuable comments on an initial draft of the article, the participants of the Social History Society conference at Putteridge Bury, Bedfordshire, January 1994, who braved snow and ice to give me a critical audience, and the graduate students in my modern British colloquia on whom the arguments were first inflicted.

${ }^{1}$ Papers of Arthur Creech Jones, Rhodes House Library, Oxford, MS British Empire S 332, box 1, file 2, fols. 194-97, n.d.: manuscript account of his thoughts in Wandsworth prison; quoted with permission from Violet Creech Jones.

${ }^{2}$ In addition, thirty-three were punished by death, twenty-one were fined, and 245 were transported; see Leon Radzinowicz and Roger Hood, The Emergence of Penal Policy, vol. 5 of A History of English Criminal Law and Its Administration from 1750 (London, 1986), p. 777. In a move to privatize punishment, public executions were abandoned in 1868; thereafter, hanging took place behind prison walls; see V. A. C. Gatrell, The Hanging Tree: Execution and the English People, 1770-1868 (Oxford, 1994), pp. 589-

Journal of British Studies 36 (July 1997): 285-324

(C) 1997 by The North American Conference on British Studies.

All rights reserved. 0021-9371/97/3603-0002\$02.00 
prisons were plugging the gap left by the end of transportation to Australia. The three hundred or so local prisons in the 1830s, to which offenders were sent for anywhere between one day and two years (though typically for terms of less than three months), were locally controlled until 1877 and were less than uniform in regime. The separate system of prison discipline (or cellular isolation) increasingly prevailed over the silent system (or associated, silent labor), but it was subject to considerable local modification. Convict prisons were run by central government with less variability. Offenders sentenced to the longer terms of penal servitude spent the first nine months separately confined in a prison like Pentonville, the symbol since its foundation in 1842 of the penitential ideal, and the bulk of the sentence at a "public works" prison like Dartmoor, working silently in association, until release on license. These differences aside, the regime behind the tall perimeter walls of most Victorian prisons inclined to one of hygienic and routinized order, cellular surveillance, and religious indoctrination. ${ }^{3}$

The first rays of reformist zeal were soon obscured by the clouds of deterrence that rolled in during the 1860 s. One commission of inquiry after the next advised government to make the prisons more repressive, more deterrent, more feared. The task of making the prison regime exacting and uniform went to Edmund Du Cane, chairman of the Directors of Convict Prisons and an administrative martinet. From 1869 until his retirement in 1895, Du Cane turned the convict prison system into "a huge punishing machine," in the words of the Irish Fenian Michael Davitt, ${ }^{4}$ and from 1877, when the Prison Act brought local prisons under central government control, he unified and streamlined the local prison structure. Two features distinguished Du Cane's penology: an inflexible

611; R. McGowen, “Civilizing Punishment: The End of the Public Execution in England,' Journal of British Studies 33 (July 1994): 257-82.

${ }^{3}$ See U. Henriques, "The Rise and Decline of the Separate System of Prison Discipline," Past and Present, no. 54 (1972): 61-93; Victor Bailey, ed., Policing and Punishment in Nineteenth Century Britain (London, 1981), pp. 11-24; Michael Ignatieff, "State, Civil Society, and Total Institutions: A Critique of Recent Social Histories of Punishment," in Crime and Justice: An Annual Review of Research, ed. M. Tonry and N. Morris, vol. 3 (Chicago, 1981), pp. 153-92; S. McConville, A History of English Prison Administration, 1750-1877 (London, 1981), chaps. 6-8, 11-13; M. DeLacy, Prison Reform in Lancashire, 1700-1850 (Stanford, Calif., 1986); J. A. Sharpe, Judicial Punishment in England (London, 1990), pp. 61-87; Clive Emsley, "The History of Crime and Crime Control Institutions, c. 1770-c. 1945,' in The Oxford Handbook of Criminology, ed. M. Maguire, R. Morgan, and R. Reiner (Oxford, 1994), chap. 4. Pentonville was initially used for convicts aged eighteen to thirty-five who were sentenced to transportation for their first offense. They spent eighteen (later reduced to nine) months in separate confinement before going to the penal colony. The period of separate confinement was applied to all penal servitude sentences after 1857.

${ }^{4}$ Quoted in Radzinowicz and Hood, p. 545. 
adoption of deterrence as the primary aim of punishment, and a rigid adherence to the uniform enforcement by the prison authorities of the court-ordered punishment. Thus, Du Cane put into practice what the "classical school" of criminal law and penal policy had preached since the eighteenth century. Since individuals had freedom of choice in deciding whether or not to commit crime, they should be deemed to be responsible; hence punishment, to be effective, should deter, and it should be strictly proportionate to the gravity of the crime. On the surface, the results of "classical" penal policy were impressive. Between 1879 and 1894 , the daily average population in convict prisons fell by over half, from 10,880 prisoners to 4,770, and the population of local prisons fell by one-third, from 20,833 prisoners to 13,850 . The drop in the prison population was probably less a function of prison discipline, however, than of the fall in recorded crime, a reduction in the minimum duration of penal servitude (from 7 years to 3 years), and an increasing resort by courts to noncustodial penalties. For every 1,000 offenders sentenced at higher and summary courts in 1896 for indictable crimes, 516 were imprisoned, 19 sentenced to penal servitude, 194 fined, 120 bound over in their recognizances, and 34 sent to reformatory and industrial schools. ${ }^{5}$ As the century of the prison drew to a close, the confidence in deterrent imprisonment was decidedly on the wane.

In 1895, two events brought the secret world of the Du Cane regime to public attention. The Departmental Committee on Prisons, under the chairmanship of Herbert Gladstone, issued its report, and Oscar Wilde, found guilty of homosexual acts, began a sentence of two years' imprisonment with hard labor. ${ }^{6}$ In both cases, the medium that brought prison conditions to public attention was the press. ${ }^{7}$ The Liberal newspaper The

${ }^{5}$ See ibid., chap. 16, and p. 777; Sharpe, pp. 66-67, 85; V. A. C. Gatrell, "The Decline of Theft and Violence in Victorian and Edwardian England," in Crime and the Law, ed. V. A. C. Gatrell, B. Lenman, and G. Parker (London, 1980), chap. 9. Du Cane's rigorous administration of the local prison system is exhaustively detailed in Sean McConville, English Local Prisons, 1860-1900: Next Only to Death (London, 1995), chaps. 410. For the "classical school," see Ian Taylor et al., The New Criminology (London, 1973; 4th impression, London, 1977), pp. 2-5.

${ }^{6}$ Herbert Gladstone was first commissioner of works in the Liberal government and previously parliamentary undersecretary at the Home Office.

${ }^{7}$ Report from the Departmental Committee on Prisons, C. 7702, Parliamentary Papers (PP), 1895, vol. 56, p. 5. For a full account of the vigorous public campaign for a prison inquiry, see McConville, English Local Prisons, chap. 13. The Irish nationalists in Parliament, many of whom had been imprisoned for political offenses, were also critical of prison administration. Their influence was strong enough to get one of their number, Arthur O'Connor, onto the Departmental Committee. See Michael Davitt, The Prison Life of Michael Davitt, Related by Himself (Dublin, 1882), pp. 10-18, and "Criminal and Prison Reform,' Nineteenth Century 36 (December 1894): 875-89; Hansard Parliamentary Debates, 3d ser., vol. 319 (August 22, 1887), col. 1485 (Arthur O'Connor). 
Daily Chronicle had taken the lead in January 1894 with a set of articles entitled "Our Dark Places." "It has long been presumed that the author of these articles was the assistant chaplain of Wandsworth prison, W. D. Morrison, but it now seems certain that the assistant editor, H. W. Massingham, wrote them, having toured a number of Her Majesty's prisons in the previous autumn. ${ }^{9}$ Likewise, news of Oscar Wilde's prison treatment appeared in the columns of the Daily Chronicle, as did Wilde's two letters on prison reform written on release from Reading Gaol. ${ }^{10}$ Massingham followed Wilde's case closely and urged W. T. Stead, editor of the Pall Mall Gazette, to do the same. "Don't forget the horror of the [prison] system," wrote Massingham, "which continually presses on my imagination since I went the round of the prisons. The whole thing is torture \& nothing but torture. Oscar Wilde is being slowly starved to death, \& is now little better than an hysterical imbecile." 11

The main burden of the indictment against the Du Cane regime was that a highly centralized system of prison administration gave attention to "organization, finance, order, health of the prisoners, and prison statistics" but treated prisoners "as a hopeless or worthless element of the community." 12 A prison regime characterized by inflexible discipline, rigid uniformity, and separate confinement was not even acting as an effective deterrent: prisons held, nay manufactured, increasing numbers of recidivists. The present principles of prison discipline, the Reverend Morrison charged, were so "debilitating," as evinced by the amount of insanity and suicide in local prisons, that they turned the casual offender into "a gaol-made criminal, the most dangerous class of all, and the most incorrigible." ${ }^{13}$ In response to the growing dissatisfaction with the prison regime, the Gladstone Committee expressed the cautious hope that deter-

${ }^{8}$ See John Stokes, In the Nineties (Chicago, 1989), pp. 96-99; A. F. Havighurst, Radical Journalist: H. W. Massingham (1860-1924) (Cambridge, 1974), p. 65.

${ }^{9}$ See McConville, English Local Prisons, pp. 554-77; Stokes, p. 96; Radzinowicz and Hood, p. 574. See also W. D. Morrison, "Are Our Prisons a Failure?" Fortnightly Review 55 (April 1894): 459-69. For Morrison's evidence to the Gladstone Committee, see Minutes of Evidence to the Departmental Committee on Prisons, C. 7702-I, PP, 1895, vol. 56, pp. 158-84.

${ }^{10}$ Letters, Daily Chronicle (May 27, 1897; March 24, 1898), reprinted in Oscar Wilde, The Soul of Man and Prison Writings (Oxford, 1990), pp. 159-67, 190-96. Wilde completed his sentence on May 19, 1897.

${ }^{11}$ Quoted in Havighurst, p. 67. See Richard Ellmann, Oscar Wilde (New York, 1988), pp. 479-532.

${ }^{12}$ Report from the Departmental Committee on Prisons, C. 7702, PP, 1895, vol. 56, p. 11, par. 23.

${ }_{13}$ Morrison, "Are Our Prisons a Failure?" p. 468. See Christopher Harding, “" "The Inevitable End of a Discredited System'? The Origins of the Gladstone Committee Report on Prisons, 1895," Historical Journal 31 (1988): 598-600; McConville, English Local Prisons, pp. 559-61, 581-83. 
rence and reform could be pursued at one and the same time as the "primary and concurrent objects" of prison treatment within a prison structure in which unproductive hard labor would be eliminated, the time spent in separate confinement reduced, and educational and trade-training services developed. More radical proposals followed for young offenders and recidivists, characterized by longer detention and special institutions. ${ }^{14}$

Meanwhile, between June 1895 and May 1897, Oscar Wilde served his sentence of two years' hard labor, a term that the Gladstone Committee judged to be more than a man could endure and that the 1898 Prison Act would ultimately abolish. Each day during the first month, prisoners climbed the equivalent of 6,000 feet on the treadmill, a purely penal form of labor. Wilde was declared unfit for first-class labor by the medical officer and so was excused from the treadmill. Each night, however, he slept on a bare plank bed. After the first month, Wilde worked in silence stitching mailbags or picking oakum (tearing old rope to pieces for the loose fiber used in caulking). In silence, too, he attended chapel each morning (twice on Sunday) and took daily exercise in single file for an hour in the open air. After the first three months, he could write four letters a year, all vetted and censored before they were dispatched, and see friends four times a year for no more than twenty minutes each time. ${ }^{15}$ An attack of dysentery put Wilde into the prison infirmary for two months and led to some improvement in his dietary lot. Additional relief came in the shape of the Liberal lawyer, R. B. Haldane, who, as a member of the Gladstone Committee, had the authority to enter any prison and make the governor produce any prisoner. He visited Wilde in Pentonville and agreed to get him books of his choice. He also visited the prisoner in Wandsworth and subsequently persuaded the home secretary to transfer Wilde to Reading, where he was assigned to light work in the garden and in book distribution. For his troubles, Haldane later received a copy of Wilde's celebrated work, The Ballad of Reading Gaol (1898), written on his release from prison. ${ }^{16}$

The rise of the prison as the main, not to say symbolic, form of punishment in the nineteenth century has concentrated the minds of a number of historians in the past twenty-five years. One question, above

${ }^{14}$ See W. R. Cornish and J. Hart, Crime and Law in Nineteenth Century Britain (Dublin, 1978), pp. 38-39; Radzinowicz and Hood (n. 2 above), pp. 576-79; McConville, English Local Prisons, chap. 15.

${ }^{15}$ See Ellmann, p. 480; Wilde's letter to the Daily Chronicle (March 24, 1898), in Wilde, The Soul of Man, pp. 193-94.

${ }^{16}$ R. B. Haldane, An Autobiography (London, 1929), pp. 166-67; Ellmann, p. 495; Wilde, The Ballad of Reading Gaol, lines 559-70, in Wilde, The Soul of Man, pp. 18687; McConville, English Local Prisons (n. 5 above), pp. 598-99. 
all, has guided their work: why, between 1780 and 1840, was the penitentiary conceived and constructed? And one explanation has taken center stage: the origins of this revolution in punishment are to be found less in the humanitarian sensibility of prison reformers, whether evangelical or utilitarian (which an older historiography underlined), and more in the desire of elite groups to isolate the criminal class, to shape a disciplined workforce, and to cope with the social dislocations of a new industrial order. Humanitarian sensibility is traced back to its supposed source in economic interest or the will to power. ${ }^{17}$ Twelve years ago, however, David Garland's Punishment and Welfare (1985) offered a new approach to the origins of the modern English penal system. ${ }^{18}$ In particular, Garland converted the blueprint offered by the Gladstone Report (1895) into the starting point of the "modern penal complex"' and, in so doing, shifted the timing of the transition to "modern penality" from the birth of the penitentiary to the Edwardian period. Between 1895 and 1914, according to Garland, the conceptual domain defined by the "classical" jurisprudential principles of individual moral responsibility, deterrence, and just proportion between crime and punishment, and the Victorian penal structure that rested on these principles, were replaced by a new "positivist" criminology and by the "modern penal complex." 19

The main tenets of "positivist"' criminology were, first, that criminal behavior was determined by factors and processes that could be discovered by observation, measurement, and inductive reasoning, the methods used by the natural and social sciences. Second, since people were impelled to commit crime by constitutional and environmental forces beyond their control and, thus, were not responsible for their actions, treatment, not punishment, was the most appropriate legal response. Third, the delinquent was fundamentally different from normal, law-abiding citizens. In the twenty years following Cesare Lombroso's L'Uomo delinquente (1876), the founding text of positivist criminology, numerous congresses, associations, and journals promoted a positivist diagnosis of criminal behavior and linked it to a new model of criminal justice. Pro-

${ }^{17}$ See Michel Foucault, Discipline and Punish: The Birth of the Prison (1975; reprint, London, 1977); M. Ignatieff, A Just Measure of Pain: The Penitentiary in the Industrial Revolution, 1750-1850 (New York, 1978). See also Victor Bailey, "The Fabrication of Deviance: 'Dangerous Classes' and 'Criminal Classes' in Victorian England,' in Protest and Survival: Essays for E. P. Thompson, ed. J. Rule and R. Malcolmson (London, 1993), pp. 221-56. 1985).

${ }^{18}$ David Garland, Punishment and Welfare: A History of Penal Strategies (Aldershot,

${ }^{19}$ Ibid., chap. 1. See also David Garland, "The Criminal and His Science: A Critical Account of the Formation of Criminology at the End of the Nineteenth Century," British Journal of Criminology 25 (April 1985): 109-37. 
portionate punishment was rejected in favor of a system of sanctions adapted to the reformability or "dangerousness" of the individual offender. An exclusively deterrent system of criminal justice was rejected in favor of one that would prevent, treat, and eliminate delinquency. ${ }^{20}$ The proponents of this scientific criminology, along with advocates of the eugenic program (who claimed that criminality, like feeblemindedness and alcoholism, was a heritable "degenerate" characteristic), and prison administrators all took part, according to Garland, in the complex administrative and legislative process that lay the foundations of modern penality. The notable milestones on this twenty-year legislative road were the Prison Act (1898), the Inebriates Act (1898), the Prevention of Crime Act (1908), and the Mental Deficiency Act (1913). Under these enactments, special institutions were established for the extended training or segregation of "habitual drunkards," "habitual criminals," and the "mentally defective." The new penal forms, finally, were part of a much wider social and political transformation, according to Garland. The new penality was tightly linked to the social principles and strategies that would become known as the Welfare State. ${ }^{21}$

Punishment and Welfare owes an obvious, if largely unacknowledged, intellectual debt to Michel Foucault's Discipline and Punish (1975). Garland and Foucault examined different fault lines, but they adopted the same method of sinking a shaft into the culture of a particular period and excavating its episteme or the deep structure of knowledge at work in that society. Moreover, Garland translated Foucault's conception of change by radical shifts from one discursive formation or episteme to another, into a recognizable historical and political reality. And last, Garland shared Foucault's view that the reforms we tend to describe as rational, progressive, and humanitarian in fact constituted a new strategy for the more effective exercise of social control: "Not to punish less,

${ }^{20}$ Cesare Lombroso, L'Uomo delinquente (Milan, 1876). See L. Radzinowicz, Ideology and Crime (New York, 1966), pp. 50-56; David Matza, Delinquency and Drift (1964), chap. 1; Taylor et al. (n. 5 above), pp. 10-23; D. Garland, "Of Crimes and Criminals: The Development of Criminology in Britain," in Maguire et al., eds. (n. 3 above), pp. 37-42.

${ }^{21}$ Garland, Punishment and Welfare, chaps. 3-5, and Punishment and Modern Society: A Study in Social Theory (Chicago, 1990), pp. 206-9. And see Harding, p. 608. In recent years, Garland has enriched his approach to the history of "penality" by incorporating discussion of the links between penal institutions and cultural phenomena; see Punishment and Modern Society, chaps. 9-11. Nonetheless, he stands by his original conception of a new Edwardian "penal-welfare complex," characterized by "its distinctively positive approach to the reform of deviants, its extensive use of interventionist agencies, its deployment of social work and psychiatric expertise, its concern to regulate, manage, and normalize rather than immediately to punish, and of course its new 'welfarist' selfrepresentation"' (ibid., p. 128). 
but to punish better . . . to insert the power to punish more deeply into the social body." 22

More recently, Martin Wiener's Reconstructing the Criminal (1990), while critical of Garland's exclusively political interpretation of criminal policy, and while concerned to show the role of culture, values, and sensibilities in the shaping of penal history, presented an account of the transformation of criminal justice from the penal crisis of the $1890 \mathrm{~s}$ to the outbreak of war in 1914 that differed little in essentials from that of Garland. In the last quarter of the nineteenth century, according to Wiener, society lost confidence in the inherent responsibility of individuals. Crime was increasingly ascribed, not to willful utilitarian calculation, but to inherited mental or physical deficiency. Accordingly, reformers no longer sought to "remoralize" the criminal-to develop the moral character necessary for leading a law-abiding life-but to "demoralize" the criminal - to uncover the physiological and environmental (or "natural') roots of criminal behavior. Wiener, like Garland, contended that the new image of criminal man owed a good deal to the force of the human sciences and, notably, positivist criminology. And the network of penal measures grounded on this new image of man represented, for Wiener, too, a major structural change in the penal complex. ${ }^{23}$

The shift in "mental frame" and the enactment of positive penology owed not a little, argued Wiener, to changes in Home Office personnel and to the reforming Liberal governments of 1906-14. The first generation of career civil servants, "less moralistic or legalistic than their predecessors . . . more attracted to the idea of scientific administration," assumed positions of influence in the Home Office and Prison Commission in the $1890 \mathrm{~s} .{ }^{24} \mathrm{~A}$ case in point was Evelyn Ruggles-Brise, who entered the Home Office in 1881 and replaced Du Cane as chairman of the Prison Commission in 1895. Likewise, a new generation of politicians took the tiller. Herbert Gladstone, who chaired the Gladstone Committee, became home secretary in the 1906 government and enacted the committee's two proposals concerning habitual criminals and young adult offenders. His successor, Winston Churchill, was more visionary still, instructing his officials to draft plans for a scientific penal system. By 1914, then, as Wiener concluded, "the rationales of deterrence and disciplinary moralization were yielding to those of welfarist administration. After the First World War, the seeds planted in the late Victorian and Edwardian years

${ }^{22}$ Foucault, p. 82.

${ }^{23}$ Martin J. Wiener, Reconstructing the Criminal: Culture, Law, and Policy in England, 1830-1914 (Cambridge, 1990), chap. 6.

${ }^{24}$ Ibid., p. 339. 
came to fruition, and the criminal justice system was thoroughly reorganized according to the new vision of criminality and its solution." 25

I wish to offer a different interpretation of the years 1895-1914, and, by extension, to 1922 , one that seeks, first, to argue for a more limited alteration in the structure of criminal justice, second, to reconstruct the penal culture of this period in its full complexity, and third, to highlight what I take to be the truly significant change in penal practice in the quarter century following the Gladstone Report, the massive abatement of imprisonment. ${ }^{26}$ These years are simply not intelligible in terms solely of an emerging positivism or medicalism. David Garland and Martin Wiener, in my view, placed far too much emphasis on positivist criminology and the associated alterations in the practice of criminal justice. The intellectual roots of what happened, and what failed to happen, in the realm of penality need to be sought elsewhere: in a radical humanitarianism, in the writings of the Philosophical Idealists, and in ethical socialism. ${ }^{27}$ The most critical change in these years - the recognition of the worthlessness of short-term imprisonment, and the related "decentering" of the prison in the system of judicial punishments-needs greater emphasis and evaluation than it has received. I begin this reassessment of the changes and continuities in the penal policy and practice of late Victorian and Edwardian England by arguing that alterations in the structure of the penal complex have been exaggerated in recent scholarship.

\section{II}

The first legislative response to the Gladstone Committee's reporta report that simply proposed ameliorating the cruelty and inhumanity of prison discipline, and the grafting of a limited number of treatment and training initiatives to the existing body of punishment and moral

${ }^{25}$ Ibid., p. 379. McConville, English Local Prisons, chap. 12, also emphasizes the contribution of a new generation of Home Office clerks, including Ruggles-Brise, to penal change. McConville makes no attempt, however, to engage with the important discussion of the influence of positivist criminology on English penal policy and administration. Lombroso is mentioned only in relation to Du Cane's penal thought (p. 182); positivism is referred to but once, with regard to W. D. Morrison (p. 562, n. 59); Garland receives three inconsequential footnotes, Wiener none. Indeed, Wiener's Reconstructing the Criminal does not even figure in McConville's bibliography.

${ }^{26}$ In this I have built on the suggestive remarks to be found in Radzinowicz and Hood (n. 2 above), chaps. 1, 17; and W. J. Forsythe, Penal Discipline, Reformatory Projects and the English Prison Commission, 1895-1939 (Exeter, 1990), chap. 1.

${ }^{27}$ See Jose Harris's convincing reassessment of the role of Idealist thought in the development of the welfare state: "Political Thought and the Welfare State, 1870-1940: An Intellectual Framework for British Social Policy,' Past and Present, no. 135 (May 1992): 117-39. 
improvement-was the Prison Act, 1898. The primary object of the measure, according to the home secretary, Matthew White Ridley, was "the creation of powers for applying differential treatment or classification . . . to our prison population." ${ }^{28}$ The act established three separate divisions for those sentenced to imprisonment without hard labor. Prisoners placed in the first division, for example, were excused the first month of separate confinement. Yet significantly-and in fairness, the point is not lost on David Garland-a classification that was meant to determine the conditions under which an offender would serve his sentence was left, pace the positivist program, to the sentencing court, not the prison executive. The criteria to be followed by the courts, moreover, included both individualization - the offender's "character" and "antecedents" - and neoclassical concerns - the "nature of the offense" and "'special provocation."' Undaunted, Garland described the act's classifications as a "discursive bridgehead to later and more fundamental changes." 29 In fact, the experiment was a failure since the courts seldom used any but the third and most severe classification. In 1912-13, thirtyseven males and one female were placed in the first division, mainly for offenses against the Elementary Education Acts; 869 males and 246 females got the second division, or roughly 1 percent of persons admitted into local prisons. ${ }^{30}$

The 1898 act also conferred on the home secretary the power to make rules for prison administration without seeking fresh legislation, abolished all forms of penal labor (including the treadmill and handcrank), and allowed local prisoners to earn remission of up to one-sixth of their sentence..$^{31}$ Of all the minor improvements made prior to the war, however, the most important concerned the term of solitary or separate confinement endured by every convict prisoner for the first few months of a penal servitude sentence and by every local prisoner sentenced to

${ }^{28}$ Hansard Parliamentary Debates, 4th ser., vol. 55 (March 24, 1898), col. 837. See Garland, Punishment and Welfare (n. 18 above), pp. 216-17. The most complete account of the 1898 Prisons Bill, and of the unsuccessful press and parliamentary campaign to deepen its reforming effect on the prison system, is in McConville, English Local Prisons (n. 5 above), chap. 17. The Second Reading of the Bill prompted Oscar Wilde to write to the Daily Chronicle (March 24, 1898), to catalog what he termed the "three permanent punishments authorised by law in English prisons": hunger, insomnia, and disease. See Wilde, The Soul of Man (n. 10 above), pp. 190-96. See also McConville, English Local Prisons, pp. 708-10, 755-56.

${ }^{29}$ Garland, Punishment and Welfare, p. 217. See W. D. Morrison, "Prison Reform: I.-Prisons and Prisoners," Fortnightly Review 63 (May 1898): 781-89.

${ }^{30}$ See Report of the Indian Jails Committee, 1919-20, Cmd. 1303, PP, 1921, vol. 10, pp. 447-50.

${ }^{31}$ See the Advisory Council on the Penal System, Sentences of Imprisonment: A Review of Maximum Penalties (London, 1978), p. 64. 
hard labor for the first month. ${ }^{32}$ The playwright John Galsworthy first concentrated the official mind in an "Open Letter to the Home Secretary" in the Nation in May 1909, in which he charged that solitary confinement was detrimental to mental, moral, and physical health to no deterrent purpose. ${ }^{33}$ Ruggles-Brise countered by arguing that solitary confinement was not retained on grounds of deterrence but "in order to give the necessary penal character to a sentence of penal servitude in the same way as a month's separate confinement is maintained in local prisons as the penal element of the sentence of hard labor." ${ }^{34} \mathrm{He}$ was willing, however, to limit the duration of strict cellular isolation to three months for all classes serving a sentence of penal servitude. Gladstone, now home secretary, agreed; hence, Galsworthy was told that a uniform term of three months' separate confinement for all convicts would come into force on April 1, 1910. For Galsworthy, it was "a big step in the right direction," but not the end of the campaign. ${ }^{35}$ Winston Churchill's appointment as home secretary brought fresh hope.

As Churchill took up the reins of office, Galsworthy urged him "to strike the finishing blow at a custom which continues to darken our humanity and good sense." Churchill asked the prison commissioners for the main arguments against the total abolition of the system of separate confinement. ${ }^{36}$ But Galsworthy left nothing to chance. He highlighted the detrimental effects of such confinement in his new play Justice, first produced in February 1910. The play's high point is a three-minute prison scene in which a young clerk, imprisoned for forgery, beats helplessly on his cell door, racked by the mental torture of solitary confinement. The scene, in which no word is spoken, profoundly affected the audience. Both Churchill and Ruggles-Brise went to see the play, the latter concluding that it was unfair because "it makes an abnormal case typical of the system." ${ }^{37}$ Churchill, however, insisted on a reduction in

${ }^{32}$ More strictly, the period of separate confinement undergone by convicts was three months for the "Star" class, six months for "Intermediates," and nine months for recidivists and revokees. alism.

${ }^{33}$ Nation (May 1, 8, 1909). The Nation was the main mouthpiece of the New Liber-

${ }^{34}$ Public Record Office (PRO), London, Prison Commission (P.Com.) 7/308; E. Ruggles-Brise memo, June 10, 1909, P.Com. 7/309.

${ }^{35}$ PRO, P.Com. 7/309; H. V. Marrot, The Life and Letters of John Galsworthy (London, 1935), pp. 250, 677; E. Garnett, ed., Letters from John Galsworthy, 1900-1932 (London, 1934), p. 174.

${ }^{36}$ Marrot, pp. 676-78.

${ }^{37}$ J. Galsworthy, Justice (New York, 1910), pp. 81-84; E. Ruggles-Brise to W. Churchill, March 21, 1910, PRO, P.Com. 7/309. C. F. G. Masterman, parliamentary undersecretary at the Home Office, told Galsworthy at a Nation lunch in April that "he, had turned the Home Office upside down with Justice"; quoted in Havighurst (n. 8 
the term of separate confinement, and a compromise was reached with the Prison Commission whereby separate confinement would be limited to one month for all convicts, except for "old lags," who would continue to serve three months. If unsuccessful in his quest for abolition, Galsworthy took comfort from the reckoning that his writings had helped "to knock off 1000 months of Solitary Confinement per year.", 38

This change aside (which brought no improvement for the large body of local prisoners), the Victorian prison system remained essentially inviolate. Nothing better illustrates how the new rules introduced under the 1898 Prison Act were simply a development, on less repressive lines, of the older system of prison discipline, than the fact that twenty years on from the act, prison administration came under a barrage of criticism quite as heavy as that which had provoked the appointment of the Gladstone Committee. And it emerged that little had truly changed.

Ruggles-Brise's regime came under the critical scrutiny of the "absolutist" conscientious objectors, "unaccustomed travellers into this valley of shadow," as Margery Fry, Quaker secretary of the Howard League for Penal Reform, so appositely termed them. ${ }^{39}$ Over 16,000 men were conscientious objectors during the First World War, but only the 1,350 who took up an "absolutist" position and refused alternative work were subject to the treadmill of arrest, court-martial, prison, release, and arrest. The practice quickly developed of commuting the original sentence of two years' imprisonment with hard labor to 112 days, which, with 'good conduct," meant just over three months in prison. Repeated sentencesand some conscientious objectors served three, four, and even five such sentences-meant that many conscientious objectors served more than two years' hard labor, the maximum sentence that could normally be imposed. ${ }^{40}$ It also meant that conscientious objectors underwent the first month's separate confinement at regular intervals; a first month of spare diet, bare wooden plank for a bed, work done in cellular isolation, and no contact with the world outside. ${ }^{41}$ There was little advance here on Oscar Wilde's treatment! The "first month" regulation, in fact, was

above), p. 163. Galsworthy kept up the pressure with a Penal Reform League leaflet, The Spirit of Punishment (London, 1910).

${ }^{38}$ Marrot, p. 266; Times (July 23, 1910), p. 4, letter from Galsworthy; PRO, P.Com. 7/310. See Paul Addison, Churchill on the Home Front, 1900-1955 (London, 1992), p. 113.

${ }^{39}$ S. Margery Fry, "The State in Its Relation to Law-Breakers," Friends Fellowship Papers (May 1920): 67. She also mentioned the prison experiences of the militant suffragists.

${ }^{40}$ Philip Viscount Snowden, An Autobiography (London, 1934), 1:410; T. C. Kennedy, "Public Opinion and the Conscientious Objector, 1915-1919," Journal of British Studies 12 (May 1973): 113.

${ }^{41}$ See David Boulton, Objection Overruled (London, 1967), p. 220. 
abandoned for second and subsequent terms as the war dragged on, and from January 1918 some conscientious objectors were permitted to talk during exercise. ${ }^{42}$

Not surprisingly, perhaps, conscientious objectors were horrified by the inhumanity of the prison regime, and especially by the dehumanizing effects of the silence rule. No conversation was allowed either with other prisoners or with prison warders, except to answer a warder's question or to make an official request. For rebelling against the silence rule, Fenner Brockway, the young socialist who, with Clifford Allen, had formed the No-Conscription Fellowship (which orchestrated the movement of resistance to conscription and acted as the guardian of the conscientious objectors), received eight months' solitary confinement and three months' bread and water. ${ }^{43}$ If some conscientious objectors complained of the semistarvation diet, some the intense cold, and some the monotony of sewing post office mailbags, all conscientious objectors bore witness to the silence rule as the most arduous of all prison regulations. ${ }^{44}$ Let Arthur Creech Jones, a junior civil servant, socialist, and conscientious objector stand proxy for them all. At some date between 1916 and 1919, Creech Jones smuggled out his uncensored thoughts in prison. "The whole system," he declared, "is based on fear." You want to live a normal healthy life while in prison, he continued:

But instead you meet your friends and you dare not speak. You dare not show any comradeship or even geniality. Often to speak pleasantly to an officer is to earn his rebuke. You must live in complete isolation, your self all hedged round as if you were a thing without a personality or soul. You must ever be stoical, never laugh, hum, whistle, sing or speak in case you are punished by bread \& water diet and solitary confinement in a bare cell

${ }^{42}$ See J. W. Graham, Conscription and Conscience: A History, 1916-1919 (London, 1922), pp. 298-99.

${ }^{43}$ See Boulton, p. 223; Hubert W. Peet, "Some Fruits of Silence," Friends Quarterly Examiner (April 1920): 127-30. Most of the leadership and the rank and file of the NoConscription Fellowship were from the Independent Labour Party (ILP) and the Quaker Society of Friends; see Kennedy, "Public Opinion and the Conscientious Objector, 19151919," p. 107.

${ }^{44}$ See R. C. Wallhead, "In Jail," Socialist Review 15 (April-June 1918): 175; Martin Gilbert, Plough My Own Furrow: The Story of Lord Allen of Hurtwood as Told through His Writings and Correspondence (London, 1965), pp. 62, 66-68; E. Williamson Mason, Made Free in Prison (London, 1918), pp. 134-35, 191-92; T. Corder Catchpool, On Two Fronts (London, 1918), p. 171; S. Hobhouse, An English Prison from Within (London, 1919), pp. 29, 33; A. Fenner Brockway, "Prisons as Crime Factories" (ILP pamphlet, London, 1919), pp. 4-8. If the silence rule were truly enforced, said Brockway, 90 percent of prisoners would lose their reason within a few months. See the comments made by the Poplar councillors imprisoned in September 1921 in N. Branson, Poplarism, 1919-1925: George Lansbury and the Councillors' Revolt (London, 1979), pp. 67-68. 
without work or reading material. The general result is that you are made cunning and crafty $\&$ adopt all manner of subterfuge to escape the vigilance of the warders. You go to church and have to sit under eyes that watch you as if they were hawks, you march 3 yards apart at exercise under the eyes of 3 or 4 officers, you work after your first month of solitary confinement under the stern face of an officer who stands on a raised platform, you sit in your cell and never sew but some eyes are not watching you through the spy hole in the door. . . . It is this feeling of isolation at the worst and most miserable moments that ever come to men, this feeling of eternal surveillance, this deprival of initiative and stripping of men of their personality, this submission to ignorance and abuse which make men bitter and anti-social. ${ }^{45}$

By war's end, many of the conscientious objectors were broken in health. ${ }^{46}$ But many also were eager to publicize further the state of English prisons and to effect some reform.

Margaret Hobhouse was the first to use letters written from prison. In I Appeal unto Caesar (1917), most of which was ghost written by Bertrand Russell, acting on behalf of the No-Conscription Fellowship, Hobhouse pleaded the case of the absolutists, one of whom, Stephen, was her son. ${ }^{47}$ Of greater importance was the Prison System Enquiry Committee established in January 1919, by the executive of the Labour (formerly Fabian) Research Department. Instrumental in the appointment of this Committee was Mrs. Hobhouse's younger sister, Beatrice Webb; the final report, published as English Prisons To-Day, was edited by two absolutists, Stephen Hobhouse and Fenner Brockway. ${ }^{48}$ With Arthur Creech Jones's assistance, Hobhouse collected information from official documents (including a pirated copy of prison standing rules), from ques-

${ }^{45}$ Papers of Arthur Creech Jones, Rhodes House Library, Oxford, MS British Empire S 332, box 1, file 2, fols. 194-97, n.d.: account of his thoughts in Wandsworth prison, quoted with permission from Violet Creech Jones. Creech Jones also noted: "We were always in touch with the ordinary prisoners. Many of them were incorrigible, infirm, maimed; some almost utterly depraved."

${ }^{46}$ Nine conscientious objectors died in prison; approximately sixty others died later from the aftereffects of prison treatment. See John Rae, Conscience and Politics: The British Government and the Conscientious Objector to Military Service, 1916-1919 (London, 1970), p. 226.

${ }^{47}$ Mrs. Henry Hobhouse, I Appeal unto Caesar (London, 1917), pp. 44-70; Jo Vellacott, Bertrand Russell and the Pacifists in the First World War (Brighton, 1980), pp. 210-12.

${ }^{48}$ See A. F. Brockway, Inside the Left (London, 1942), pp. 126-28, and Towards Tomorrow: The Autobiography of Fenner Brockway (London, 1977), p. 61. See also S. Hobhouse and A. F. Brockway, English Prisons To-Day: Being the Report of the Prison System Enquiry Committee (London, 1922). For details of the membership of the Prison System Enquiry Committee, and for more on Hobhouse and Brockway, see p. 308 below. 
tionnaires completed by some fifty prison officials (until the Prison Commission nipped that in the bud), from agents of Discharged Prisoners' Aid Societies, and above all from 290 ex-prisoners, mainly ex-conscientious objectors. ${ }^{49}$

Witnesses who went to prison as a form of political demonstration, and who were more sensitive in mind and body than the average felon, were not, the Home Office complained, the best judges of the prison system. ${ }^{50}$ Hobhouse defended the firsthand testimony, however, on the grounds that conscientious objectors could readily communicate their prison experiences and "that the mental effects observed in the course of imprisonment can be more easily isolated from the consequences of previous habits of crime, congenital abnormalities, and such concomitants of imprisonment as social ostracism." As the finishing touches were being applied to the report, an official appraisal appeared in the form of Ruggles-Brise's English Prison System (1921)..$^{51}$ The contrast was telling: one displayed a defensive parental pride in the achievements of the past twenty-five years, while the other presented an unassailable case for the prosecution.

English Prisons To-Day was an exhaustive report of 728 pages (or a quarter of a million words), describing and evaluating the various forms of imprisonment, the different kinds of prisoner, prison food and work, and medical and sanitary treatment. At times, indeed, the excess of detail detracts from the report's effectiveness. The report is certainly longer on exposure of prison conditions than on proposals for a thoroughgoing alternative. The latter were precluded, however, by divisions in the Prison System Enquiry Committee. ${ }^{52}$ Once again, the silence rule, the first rule on the card that hung in every prisoner's cell, was named as the most pernicious feature of prison life. ${ }^{53}$ But the silence rule was, the authors insisted, "only characteristic of the whole system. Self-respect is systematically destroyed and self-expression prevented in every phase of prison existence." ${ }^{54}$ The effects of imprisonment, they claimed, "are of the nature of a progressive weakening of the mental powers and of a deterioration of the character in a way which renders the prisoner less fit for

${ }^{49}$ See Stephen Hobhouse, Forty Years and an Epilogue: An Autobiography (London, 1951), p. 176; Gordon Rose, The Struggle for Penal Reform (London, 1961), pp. 1089; PRO, Home Office (HO) 45/11543/357055/33.

${ }^{50} \mathrm{PRO}, \mathrm{HO} 45 / 11543 / 357055 / 33$.

${ }^{51}$ Hobhouse and Brockway, p. 482; E. Ruggles-Brise, English Prison System (London, 1921).

${ }^{52}$ Brockway, Inside the Left, p. 129; personal interview with Fenner Brockway, June 1980 .

${ }^{53}$ Hobhouse and Brockway, pp. 561-62.

${ }^{54}$ Ibid., p. 356. 
useful social life, more predisposed to crime, and in consequence more liable to reconviction." The distinctive feature of prison life "is the sense of being in the grip of a huge machine which is felt to be repressive at every point, inhuman, aimless, tyrannical." ${ }^{55}$ In all, English Prisons ToDay proclaimed that the guiding principles and effect of the RugglesBrise regime were barely distinguishable from those of its predecessor, the Du Cane regime. There could be no greater indictment of a quarter century during which the Gladstone Report had been implemented. ${ }^{56}$

English Prisons To-Day, according to Margery Fry of the Howard League, became "the Bible of penal reformers." 57 It inspired a number of parliamentary questions concerning insanity among prisoners and the suicide rate in prisons. ${ }^{58}$ More important, Sir Maurice Waller, the new chairman of the Prison Commission (as of August 1921), studied the volume and then, claimed Stephen Hobhouse, consulted both Sir William Clarke Hall (progressive London magistrate and Hobhouse's brother-inlaw) and Margery Fry. Moreover, a member of the Prison System Enquiry Committee, Alec Paterson, who had helped draft the section on Borstal training, was appointed to the Prison Commission and was "the guiding and most beneficent spirit of that powerful body, revolutionising a large part of prison treatment by substituting educational methods for the rigid and stupid punitive regime." ${ }^{59}$ This all perhaps exaggerates the direct influence of English Prisons To-Day since the new prison commissioners were already committed to a less repressive regime, and some of their immediate changes anticipated the recommendations of the Prison System Enquiry Committee.

To the end of a more humane treatment of prisoners, Waller persuaded the home secretary in late 1921 to abolish the close cropping of convicts' hair and to allow prisoners to see visitors without intervening wire or bars. ${ }^{60}$ But the volume doubtless strengthened Waller's arm when it came to ending the rigors of the silence rule and separate confinement.

${ }^{55}$ Ibid., p. 561. Another continuing feature of prison administration was its dreary uniformity, encapsulated by Ruggles-Brise's 1911 comment, quoted in Hobhouse and Brockway, p. 97: "It is now 4-30 in the afternoon and I know that just now, at every Local and Convict Prison in England, the same things in general are being done, and that in general they are being done in the same way."

${ }^{56}$ It should be added, however, that there had doubtless been a change in expectations since the Gladstone Report, sufficient to sharpen the postwar critique.

${ }^{57}$ Enid Huws Jones, Margery Fry: The Essential Amateur (London, 1966), p. 113.

${ }^{58}$ For example, Hansard Parliamentary Debates, 5th ser., vol. 156 (July 11, 1922), col. 1040. See also PRO, HO 45/11543/357055/54 and 55.

${ }^{59}$ Hobhouse, Forty Years and an Epilogue (n. 49 above), pp. 178-79. For Paterson, see Victor Bailey, Delinquency and Citizenship: Reclaiming the Young Offender, 19141948 (Oxford, 1987), pp. 195-96.

${ }^{60} \mathrm{PRO}, \mathrm{HO} 45 / 11033 / 428541$. 
A month after the book's publication, all prison governors were instructed to allow conversation between prisoners at labor and between warders and prisoners. ${ }^{61} \mathrm{~A}$ few months later, convinced that solitude led to morbid introspection, revengeful feelings, and suicidal tendencies, the Prison Commission got Home Office approval to suspend, for an experimental period of six months, the stage of separate confinement at the start of every convict's sentence. These arrangements were ultimately made permanent. ${ }^{62}$ And, finally, a statement of aims in the annual reports for 1924 and 1925 illustrated the new approach of the prison commissioners. Their object was to restore prisoners "to ordinary standards of citizenship" by promoting self-respect and a sense of personal responsibility. This in turn would require "vigorous industrial, mental, and moral training, pursued on considered lines by officers, teachers, and prison visitors of character and personality." 63

Yet if improvements in prison administration were evident, helped forward by Hobhouse and Brockway, by some eighteen M.P.s who shared the status of ex-prisoner, and by a reconstructed Prison Commission, the pace of penal change remained decidedly halting. ${ }^{64}$ In many prisons, claimed Fenner Brockway in 1926, the new interpretation of the silence rule had yet to find full expression. ${ }^{65}$ In the case of men sentenced to imprisonment with hard labor, moreover, the preliminary period of separate confinement (reduced from 28 to 14 days in 1919) still obtained. In September 1924, Waller pressed for its abolition, but the home secretary demurred, and the issue was dropped..$^{66}$ Not until 1931 was the period of cellular confinement entirely abolished. And the prison commissioners failed to get the Royal Commission on Prisons and Borstals they dearly wanted. An inquiry would, they believed, arouse public interest in the treatment, education, and reclamation of social failures. It would also give them the opportunity to argue that people ought not to be sent to prison at all if it could be avoided. In August 1922, the Treasury made money available for the public inquiry. Alas, the government changed,

${ }^{61}$ See Rose, The Struggle for Penal Reform (n. 49 above), p. 111; PRO, P.Com. $7 /$ 475.

${ }^{62}$ PRO, HO 45/13658/185668/21; Lionel W. Fox, The English Prison and Borstal Systems (London, 1952), p. 68.

${ }^{63}$ Quoted in Fox, pp. 70-71.

${ }^{64}$ For details of ex-prisoner M.P.s, see Snowden (n. 40 above), p. 410; Lord PethickLawrence, Fate Has Been Kind (London, 1942), p. 130; K. Robbins, "Morgan Jones in 1916," Llafur 1 (Summer 1975): 38-43. Another influence on penal change, particularly in staff conditions, was the unrest among prison officers, which found expression in the growth of the National Union of Police and Prison Officers, and in the 1919 strike.

${ }^{65}$ A. F. Brockway in Socialist Review (September, October, and December 1926).

${ }_{66}$ PRO, HO 45/13658/185668/21. 
and the next home secretary felt public demand was too weak to justify a review of the prison system. ${ }^{67}$ In short, this entire catalog of evidence should give pause to those who insist that the Edwardian years witnessed the emergence of a new penal structure.

\section{III}

Garland is perhaps on firmer ground when it comes to the separate treatment of distinct categories of offender, recommended by the Gladstone Committee for young offenders aged sixteen to twenty-three and for habitual criminals. Lengthy discussions, and some experimentation, preceded the Prevention of Crime Act, 1908, which brought into being the sentence of preventive detention, to rid society of the habitual criminal, and the Borstal training sentence, to stem the flow of new habitual offenders. Both measures are typically seen as basic components of the positivist restructuring of the penal system; both measures reflect the influence of the principles of individualization and indeterminacy. Even here, however, caution is required.

For habitual offenders, the 1908 act settled on a so-called "dual track" system. ${ }^{68}$ In an awkward alliance of classicism and positivism, those deemed to be habitual criminals first paid for their crime in the coinage of just deserts (penal servitude), after which they were detained for their habitual criminality in the new currency of social defense (preventive detention). What looked to the judiciary like double sentencing made judges so uneasy that they became extremely averse to using the measure. By 1921, only 577 convicts had been sentenced to preventive detention. ${ }^{69}$ The low number was a result not only of judicial skepticism but also of Churchill's determination, when home secretary, to restrict preventive detention to the dangerous professional criminal. The act, he believed, had pressed too largely on the persistent minor offender. ${ }^{70}$ Churchill's intervention gave the kiss of death to this new form of detention. In 1911, only 53 men were sentenced to preventive detention, as compared with 177 in the previous year. ${ }^{71}$ If the sentence of Borstal train-

${ }^{67}$ See PRO, HO 45/11543/357055/71; “"Editorial," Howard Journal 1 (1922): 4-5.

${ }^{68}$ For discussion of the definition of habitual criminality adopted by the 1908 actone that failed to distinguish clearly between the habitual professional and the habitual petty nuisance - see Wiener (n. 23 above), p. 347; Radzinowicz and Hood (n. 2 above), pp. 266-67.

${ }^{69}$ S. Petrow, Policing Morals: The Metropolitan Police and the Home Office, 18701914 (Oxford, 1994), p. 111.

${ }^{70}$ See pp. 320-22 below for Churchill's critical approach to preventive detention.

${ }^{71}$ Radzinowicz and Hood, p. 286. See also N. Morris, The Habitual Criminal (Cambridge, Mass., 1951), p. 80; Forsythe, Penal Discipline, Reformatory Projects and the English Prison Commission, 1895-1939 (n. 26 above), p. 243, and "Reformatory Projects 
ing was less troubled by a conflict of penal philosophies, it fell well short of a full-blooded positivist transplant. Ruggles-Brise saw Borstal as an alternative to penal servitude for the dangerous criminal between sixteen and twenty-one years of age and hence insisted on a regime that would build character via strict discipline, obedience, and uniform treatment. Up to and for some years beyond 1918 the conditions and regime of Borstal training were only one step removed from those of a convict prison. $^{72}$

If the net is cast wider to include the Inebriates Act, 1898 (establishing state reformatories for habitual drunkards), and the Mental Deficiency Act, 1913, the overall conclusion persists. The first-mentioned statute reflects the shift of policy toward extended custody and medical treatment of habitual drunkards. ${ }^{73}$ The other measure was one for which the eugenics movement could legitimately claim responsibility. Mental deficiency was thought to be hereditary, to be largely incurable, and to require the compulsory segregation of the "feebleminded," not to mention limitation of their right to reproduce. ${ }^{74}$ Two points establish the overall conclusion. First, evidence of the origins and workings of these acts suggest that Garland's notion of a shift in criminological understanding from the "moral" to the "medical" is overdrawn. Inebriate reformatories and mental deficiency institutions were used predominantly for females. ${ }^{75}$ Most of the committals to inebriate reformatories were for either neglect or cruelty to children or drunk and disorderly behavior. ${ }^{76}$ The most convincing explanation of this policy is that, because women, in their role as mothers, were identified as the biological source of inebriety and feeblemindedness, female offenders became subject to a process of medicalization. But these new medical and psychiatric interpretations of female crime, and this is the point of importance, were, according to Lucia

in British Prisons, 1780-1939: Recent Writings and Lessons from the Past," in History and Sociology of Crime, ed. P. Robert and C. Emsley (Pfaffenweiler, 1991), p. 54.

${ }^{72}$ See Bailey, Delinquency and Citizenship (n. 59 above), pp. 186-91, esp. p. 189.

${ }^{73}$ See Wiener, p. 188; Radzinowicz and Hood, pp. 308-13.

${ }^{74}$ Eugenics, based on the belief that the physical and mental condition of the population was determined more by heredity than environment, had an influential following up to 1914. Eugenists predicted race degeneration if the "unfit"' were allowed to reproduce themselves more rapidly than the "fit." See G. R. Searle, Eugenics and Politics in Britain, 1900-1914 (Leyden, 1976); M. Freeden, "Eugenics and Progressive Thought: A Study in Ideological Affinity," Historical Journal 22 (1979): 658; Jose Harris, Private Lives, Public Spirit: A Social History of Britain 1870-1914 (Oxford, 1993), pp. 244-45.

${ }^{75}$ See H. G. Simmons, "Explaining Social Policy: The English Mental Deficiency Act of 1913," Journal of Social History 11 (1977-78): 399; G. Hunt, J. Mellor, and J. Turner, "Wretched, Hatless and Miserably Clad: Women and the Inebriate Reformatories from 1900-1913," British Journal of Sociology 40 (June 1989): 246.

${ }^{76}$ C. Harding and L. Wilkin, “" 'The Dream of a Benevolent Mind': The Late Victorian Response to the Problem of Inebriety," Criminal Justice History 9 (1988): 198. 
Zedner, "suffused with a highly moral view of what constituted deviance and what constituted normality in women." 77 These theories, she argues, "fitted only too well with the long-standing belief that criminal women not merely broke the law but tended to exhibit fundamental flaws of character." And she concludes by saying that historians have neglected the extent to which medical responses were erected on "the foundation of older, culturally derived assumptions about women's character and behavior." 78

The second point relates to the abiding strength of the "tariff" principle of sentencing. The judiciary either committed offenders to inebriate reformatories only for terms similar to those they would have served in prison or refused to make use of them at all. The figures speak for themselves. There were approximately a quarter of a million committals to prison for drunkenness annually before 1914. Yet the total number of committals to inebriate reformatories between 1899 and 1913 was 4,590 (3,741, or 81 percent, of whom were women). The daily average population never reached 1,000. By 1921, all the reformatories had closed. ${ }^{79}$ The experiment of subjecting habitual drunkards to prolonged detention had proved a colossal failure. Only by a large stretch of the imagination, then, can penal measures that were full of philosophical ambiguity, that dealt with only a few hundred cases each year, and that were surrounded on all sides by more traditional forms of punishment be seen as composing a major alteration in the structure of criminal justice.

As a brief coda to this section, it is useful to refer to the failure, also, to establish penal labor colonies for those convicted of vagrancy. Garland struggles to explain this failure to establish the compulsory segregation of the "unemployable," which he sees as an essential deterrent underside to the "social security program" of labor exchanges and social insurance. He posits the undocumented interpretation that policy makers realized that they could instead employ the network of Borstals, preventive detention prisons, inebriate reformatories, and mental deficiency institutions. ${ }^{80}$ I prefer the more prosaic explanation that the labor colony scheme expired because a sentence of three years' detention, even as a maximum, for the crime of vagrancy was deemed unduly drastic. Thus the failure of the penal labor colony squares with the conclusion that judges (and public opinion) consistently adopted an extremely circum-

${ }^{77}$ L. Zedner, "Women, Crime, and Penal Responses: A Historical Account," in Crime and Justice: A Review of Research, ed. M. Tonry, vol. 14 (Chicago, 1991), p. 308.

${ }^{78}$ Ibid., pp. 343, 353. See Simmons, p. 393.

${ }^{79}$ Hunt et al., p. 246; Radzinowicz and Hood (n. 2 above), pp. 311-14.

${ }^{80}$ Garland, Punishment and Welfare (n. 18 above), pp. 227-28. 
spect approach to the new scientific knowledges, and they remained stubbornly reluctant to impose long preventive sentences.

\section{IV}

The way we see criminal offenders, understand their motivations, and dispose of them as cases is heavily influenced by the intellectual frameworks of the time. What patterns of thought guided the ways in which criminals were seen, understood, and treated in the Edwardian era? Garland and Wiener reply that a traditional "moral" discourse retreated before the wave of scientific determinism. They argue that these years witnessed a major sea change in criminological discourse, from classical jurisprudence to positivist medicalism, which in turn led to a tectonic shift in penal structures. ${ }^{81}$ This is not how I read the evidence. I am not convinced that a new positivist discourse, underwritten by the human sciences, dominated what could be seen, thought, and performed in the penal domain. I am not convinced that "demoralization," or a diminishing faith in the efficacy of individual willpower, was as pronounced or advanced as Garland and Wiener contend. Their interpretation underestimates the continued influence of humanitarianism as a causal factor in penal change, utterly ignores the Idealist framework of social and legal thought, and relegates the force of ethical and Christian socialism to a footnote. It is to these other discourses that I turn in order to document the complexity of Edwardian penal culture and to underline the continued and vital role of moral character in Edwardian penal thought. ${ }^{82}$

Most historians would now accept that cultural mentalities and sensibilities affect the ways in which we think about offenders. Yet too often these important moral, religious, and emotional forces are mere ghosts at the table of penal change. If we truly wish to include sensibilities in our explanatory framework, then humanitarianism should be seen not as surface rhetoric, masking more fundamental economic or political interests - the line taken by Foucault when he dismissed humanitarianism as "so much incidental music" - but as a causal factor in penal change. The humanitarian sensibility altered in character over the Victorian period. Early Victorian humanitarianism was a form of benevolence that regarded the "lower orders" with a charitable and superior eye. By the last quarter of the nineteenth century, humanitarians were no longer so

${ }^{81}$ Wiener (n. 23 above), p. 186.

${ }^{82}$ I am not arguing that ideological forms were the only influence on the penal system; I am arguing that positivism was only one, and not the most important, framework of social and political thought in the Edwardian debate on prisons. 
seized by the personal moral inadequacies of those they would redeem. Newer humanitarian feelings were emerging. Humanitarians encouraged a compassion for the weak and infirm precisely because they were weak and infirm. ${ }^{83}$

In 1891, humanitarian ranks were bolstered by the arrival of the Humanitarian League. It was founded by the socialist pacifist Henry Salt, a former master of Eton public school who retired to a Thoreau-inspired, simple life in the Surrey countryside. There he became the center of a progressive literary circle, the most famous members of which were the Fabian socialist George Bernard Shaw and the ethical socialist Edward Carpenter. The League was particularly concerned with criminal law reform, the abolition of corporal punishment, and preventing cruelty to animals and children. In 1896, the League established a criminal law and prisons department to advocate improvements in prison conditions and penal policy. The department sought to humanize the conditions of prison life and to affirm that the true purpose of imprisonment was the reformation, not the mere punishment, of the offender. ${ }^{84}$

The most striking feature of the Humanitarian League is the way it acted as an unofficial hub of penal reform between the Gladstone Report of 1895 and the Prison System Enquiry Committee's volume, English Prisons To-Day (1922). One spoke of the reform wheel radiated out to the agitation that led to the Gladstone Report and the 1898 Prison Act. The League's activities were guided by W. D. Morrison, chaplain of Wandsworth prison, Christian socialist, and criminologist, and were supported by the Irish nationalist M.P. Michael Davitt, who was on the committee of the League's criminal law and prisons department. ${ }^{85}$

${ }^{83}$ For the early nineteenth-century, humanitarian concern for the protection from abuse of prisoners and lunatics, see T. W. Laqueur, "Bodies, Details, and the Humanitarian Narrative," in The New Cultural History, ed. Lynn Hunt (Berkeley, 1989), p. 179; Andrew Scull, The Most Solitary of Afflictions: Madness and Society in Britain, 17001900 (New Haven, Conn., 1993), p. 380. See also Martin Wiener, ed., "'Special Issue: Humanitarianism or Control? A Symposium on Aspects of Nineteenth Century Social Reform in Britain and America," Rice University Studies, vol. 67 (Winter 1981). And see T. L. Haskell, "Capitalism and the Origins of the Humanitarian Sensibility, Parts 1 \& 2," American Historical Review 90 (April and June 1985): 339-61, 547-66.

${ }^{84}$ See Rose, The Struggle for Penal Reform (n. 49 above), pp. 56-57; Garland, Punishment and Welfare, p. 109; Wiener, p. 335. Salt and the Humanitarian League supported the Daily Chronicle's 1894 campaign for a prison inquiry; see McConville, English Local Prisons (n. 5 above), p. 580. For Salt's and the league's agitation against cruel sports, and for Carpenter's opposition to vivisection, see Brian Harrison, Peaceable Kingdom: Stability and Change in Modern Britain (Oxford, 1982), pp. 91, 108, 150.

${ }^{85}$ See Henry S. Salt, Seventy Years among Savages (London, 1921), p. 140; George Hendrick, Henry Salt: Humanitarian Reformer and Man of Letters (Urbana, Ill., 1977), p. 77; Forsythe, Penal Discipline, Reformatory Projects and the English Prison Commission, 1895-1939 (n. 26 above), p. 23; Dan Weinbren, "Against All Cruelty: The Humanitarian League, 1891-1919," History Workshop Journal 38 (Autumn 1994): 92-95. 
A second spoke led to the circle of progressives-Edward Carpenter, Havelock Ellis - who sought to live the new Ideal of Humanity, and who, with Morrison, condemned existing prisons- "whited sepulchres full of dead men's bones," in Carpenter's telling biblical allusion-and acted as conduits for a more "scientific" view of crime. ${ }^{86}$ Carpenter and Ellis represented advanced opinion in the 1890s. Carpenter's lifestyle was a revolt against the oppressive conventionalities of Victorian life. He crusaded for a new ideal of social brotherhood and the honest human relation. Salt's friendship drew him into the Humanitarian League and into speaking and writing on behalf of penal reform. The prisons, Carpenter advised, should be transformed into "Industrial Asylums" in which prisoners would be educated for citizenship. ${ }^{87}$ Havelock Ellis was a member of the Fellowship of the New Life, a group that viewed individual moral regeneration as the key to social reform (and from which the Fabian socialists had broken away in 1884). Ellis's Contemporary Science Series, in which his own contribution to "criminal anthropology," The Criminal, appeared in 1890, introduced Cesare Lombroso, the "criminal type,' biological determinism, and the indeterminate sentence to an English audience. Not surprisingly, his remedy for crime was resolutely positivist: to replace the word "crime" with that of "disease," in the belief that criminals needed individualized treatment. ${ }^{88}$

Positivism also attracted W. D. Morrison. The Criminology Series he edited included the work of European positivists such as Lombroso and Enrico Ferri, and Morrison's own studies stressed the deterministic (particularly biological) sources of delinquency. But Morrison's criminology was, in fact, an eclectic, often contradictory, mix of positivism, practical prison experience, and Christian socialism. To judge from his introductions to the translations of continental theorists, moreover, Morrison's attraction to positivism grew out of deep dissatisfaction with the existing prison system, and hence his main approach was to mine the new theory for scientific sanction to the humanitarian-cum-evangelistic campaign for penal reform. Anyway, Morrison's enthusiasm for positivism gradually waned. He could not ultimately accept the Lombrosian theory of degenerate "criminal man." Nor could he support the indeter-

${ }^{86}$ E. Carpenter, Prisons Police and Punishment (London, 1905), p. 120.

${ }^{87}$ See E. Carpenter, England's Ideal and Other Papers on Social Subjects (London, 1895), pp. 1-22, and Prisons Police and Punishment, pp. 61-77; C. Tsuzuki, Edward Carpenter, 1844-1929 (Cambridge, 1980), p. 113.

${ }^{88}$ Havelock Ellis, The Criminal (London, 1890). See Phyllis Grosskurth, Havelock Ellis (New York, 1980), pp. 69, 114-16; R. E. McGowen, "Rethinking Crime: Changing Attitudes towards Law-Breakers in Eighteenth and Nineteenth-Century England" (Ph.D. diss., University of Illinois at Urbana-Champaign, 1979), pp. 311-14. 
minate sentence, so foreign was it, he felt, to the English liberal tradition. ${ }^{89}$

A third spoke of the reform wheel ran from the Tolstoyans and humanitarians in the Penal Reform League to the socialists and pacifists of the Prison System Enquiry Committee. The Penal Reform League was founded in 1907, an outgrowth of the prison experience of the suffragettes and the new humanist spirit. It stood for the reclamation of criminals by a curative and educational prison system. The founder and first secretary was Arthur St. John, a Tolstoy disciple and a believer, with Salt and Carpenter, in the good in every individual. In truth, the league was a small body with no money to speak of and had little influence on the course of penal reform before 1914. This was not for want of trying. League leaflets, written by such humanitarians as the playwright John Galsworthy, advocated penal reform. St. John led deputations to the Home Office, where he complained that the prison system was having a disastrous effect on the minds and souls of prisoners and declared that the country needed a different spirit in prison administration. ${ }^{90}$ Predictably, St. John was asked to join the Prison System Enquiry Committee in 1919. Other committee members included the ubiquitous W. D. Morrison, Margery Fry, the secretary of the Howard League for Penal Reform (a 1921 amalgamation of the Howard Association and the Penal Reform League), Alexander Paterson, secretary of a voluntary society to assist discharged prisoners, Sidney and Beatrice Webb, and the guild socialist G. D. H. Cole. The chairman of the committee was Fabian socialist, Sydney Olivier, a friend of the Salts and fellow humanitarian. ${ }^{91}$

The secretary of the Prison System Enquiry Committee was Stephen Hobhouse. He emerged from prison determined to bear witness to the defects of prison conditions. "If some of our predecessors in the Society [of Friends] have a heavy responsibility fixed on them for assisting in the establishment of the false methods of to-day," wrote Hobhouse, in a reproachful reference to his Quaker forebears, "we may perhaps atone for this want of imagination by helping to inaugurate a new and more

${ }^{89}$ See McGowen, "Rethinking Crime," pp. 301-11; Radzinowicz and Hood (n. 2 above), pp. 86-88; W. D. Morrison, "The Study of Crime," Mind, no. 4 (Oct.1892): 489-517; David Garland, "British Criminology before 1935," British Journal of Criminology 28 (Spring 1988): 7; C. Lombroso and W. Ferrero, The Female Offender (New York, 1916), introduction by W. D. Morrison, pp. v-xx.

${ }^{90}$ See Galsworthy, The Spirit of Punishment (n. 37 above); Arthur St. John, Prison Regime (London, 1913), and Reception Houses (London, [1918?]); PRO, HO 45/11543/ $357055 / 16$.

${ }_{91}$ PRO, HO 45/11543/357055/33; Stephen Hobhouse, Forty Years and an Epilogue (n. 49 above), pp. 133-34; Hendrick, p. 161. For the contribution of conscientious objectors to the Prison System Enquiry Committee, see pp. 298-99 above. 
Christ like treatment of our erring fellow-creatures." ${ }^{92}$ After two years' work on the report, Hobhouse was close to a nervous breakdown. Hence Beatrice Webb asked Fenner Brockway to join her nephew, Stephen, as joint editor. A year later a report appeared under the title, English Prisons To-Day. The two authors converted the searing personal testimony of the conscientious objectors into an impeachment of the prison administration of the Prison Commission chairman, Sir Evelyn Ruggles-Brise. If one thread held together English Prisons To-Day it was that, whatever the prevailing theory of punishment, "the Prison System ought not to result in the brutalisation, deterioration, or devitalisation of the criminal, but should, as far as possible, be humane in the best sense of the word." 93

The humanitarian or "moral" approach of these various reform bodies was, for David Garland, little more than rhetoric that either served to mask power or provided legitimacy for the use of power. Thus, humanitarian values, he suggests, facilitated the acceptance by a conservative political and administrative elite of positivist penal measures. ${ }^{94}$ This reductive approach underestimates the contribution of humanitarianism to penal debate and change. Humanitarianism exists at a different level than coherent and articulated theories like positivism, idealism, or socialism; it is at once more popular, vague, and elusive. Yet if humanitarianism's weight was felt less rationally, it was an essential feature of the emotional and intellectual environment of these years. It is misleading, moreover, pace Foucault, to see humanitarianism as the antithesis of social science. Rather, the Edwardian years point to a more complex relationship between the two. A reinvigorated humanitarianism accompanied the rise of positivist criminology. As a result, humanitarians began to use more deterministic language and to propose more "scientific" remedies. Yet humanitarians also modified and limited the effect of positivist theory by their emphasis on the suffering and dignity of individual prisoners.

${ }^{22}$ S. Hobhouse, "The Silence System in British Prisons," Friends' Quarterly Examiner (July 1918): 263.

${ }_{93}$ PRO, HO 45/ 11543/ 357055/ 33; A. Fenner Brockway, Inside the Left (n. 48 above), chap. 13.

${ }^{94}$ Garland, Punishment and Welfare (n. 18 above), pp. 108-9, 123. In faimess, Garland states that the approach of the penal reform groups to the "criminological programme" was "mediated by Christian evangelicalism, which allowed a large degree of policy support, but prohibited any total endorsement of the programme as a whole" (ibid., p. 109). In more recent work, moreover, Garland acknowledges the need to include sensibilities in the examination of penal policy and speculates on the contribution of humanitarian values to change in penal laws and institutions; see David Garland, Punishment and Modern Society (n. 21 above), p. 198, "Sociological Perspectives on Punishment," in Tonry, ed. (n. 77 above), p. 142, and "Criminological Knowledge and Its Relation to Power: Foucault's Genealogy and Criminology Today,' British Journal of Criminology 32 (Autumn 1992): 411-12. 
The gravamen of the reformers' critique was that the existing prison system manifestly failed to believe in, or to revive, the good in every prisoner. No one would wish to accept at face value all the claims of the humanitarian bodies, but humanitarian sensibility deserves full recognition in an explanation of Edwardian penal debate and change.

The penal culture of these years was also deeply touched by the ideas of the Philosophical Idealists, notably the work of the Oxford professor of moral philosophy, T. H. Green. This should occasion no surprise, given the considerable influence that Idealism is known to have exerted on social thought and public policy in the late Victorian and Edwardian years. ${ }^{95}$ Yet Garland and Wiener make little or no mention of it. It is time to repair the neglect, starting with the bare essentials of this philosophical approach. ${ }^{96}$

Green believed that every man had the capacity for moral choice and the will to behave responsibly and that every man had to be encouraged to cultivate his "best self." For a man to realize his "best self," he had to will it; social institutions could not enforce self-realization. However, the state had an obligation to help the individual to further his "best self"; the state had a key role to play in creating the conditions for moral advancement. A framework of law guaranteeing certain rights (such as access to education) was the sine qua non of an individual's moral development. Rights, that is, were the powers given by the state to permit each individual to develop his moral character and contribute his best to society. In pursuing his "best self," the individual also contributed to the "common good." Moral improvement, then, was the motor of social progress. Social transformation depended on the moral im-

${ }^{95}$ See Melvin Richter, The Politics of Conscience: T. H. Green and His Age (London, 1964), p. 13, and "T. H. Green and His Audience: Liberalism as a Surrogate Faith," Review of Politics 18 (October 1956): 444. For the most recent assessment of the influence of Idealist thought on the structural transformation of welfare provision, see Jose Harris, "The Webbs, the Charity Organisation Society and the Ratan Tata Foundation: Social Policy from the Perspective of 1912," in The Goals of Social Policy, ed. M. Bulmer et al. (London, 1989), pp. 51-55, and "Political Thought and the Welfare State, 18701940" (n. 27 above).

96 The next paragraph is based on G. Himmelfarb, Poverty and Compassion: The Moral Imagination of the Late Victorians (New York, 1991), chap. 17; Adam B. Ulam, Philosophical Foundations of English Socialism (Cambridge, Mass., 1951), pp. 34-38; A. Vincent and R. Plant, Philosophy, Politics and Citizenship: The Life and Thought of the British Idealists (Oxford, 1984), pp. 2, 40, 52; J. Harris, Private Lives, Public Spirit (n. 74 above), pp. 248-50. 
provement of individual citizens. Two notions relevant for our purposes flowed from this philosophy.

One was a nondeterministic approach to human behavior. "Idealist man" willed his own destiny "instead of being driven this way and that by external forces." ${ }^{97}$ Though the state had the job of creating conditions that would enable men to realize their moral potential, state intervention was meant not to diminish individual responsibility but rather to offer a new way to promote it. The second notion was the cult of citizenship. Idealism dignified all men, even the poorest, as citizens capable of selfrealization. The disadvantaged had to be helped to achieve self-development, either by state assistance or, more suitably, by voluntary social service. This belief in active citizenship underpinned the work, for example, of the university settlement movement. ${ }^{98}$ These two notions contributed to the debate on Edwardian penal policy. The insistence on individual responsibility reinvigorated the classical philosophy and practice of punishment and provided an antidote to the excesses of positivism. The secular religion of citizenship converted a number of key prison reformers and practitioners to the belief that they had a civic duty to create penal environments in which prisoners could fit themselves for citizenship.

Idealism offered a philosophy of punishment and, indirectly, an image of "criminal man." Not for the Idealist, Lombroso's "born criminal," nor the notion of crime as degeneracy or disease requiring prolonged, if not indefinite, detention. Rather, the criminal was a moral and responsible being who had violated someone else's rights. Punishment was the state's way of securing "the future maintenance of rights." Among the rights to be maintained, however, "are included rights of the criminal himself." Green argued that "this consideration limits the kind of punishment which the state may justly inflict. It ought not in punishing to sacrifice unnecessarily to the maintenance of rights in general what might be called the reversionary rights of the criminal, rights which, if properly treated, he might ultimately become capable of exercising for the general good." "99 To be just, then, punishment ought to be proportionate to the importance of the right violated, and it ought to be "reformatory" in the sense that "it must tend to qualify the criminal for the re-

${ }^{97}$ T. H. Green, "Principles of Political Obligation," par. 7., in Works of Thomas Hill Green, ed. R. L. Nettleship, vol. 2 (1886; 5th impression, London, 1906).

${ }^{98}$ See J. Morrow, "Ancestors, Legacies and Traditions: British Idealism in the History of Political Thought," History of Political Thought 6 (Winter 1985): 510; S. Meacham, Toynbee Hall and Social Reform, 1880-1914 (New Haven, Conn., 1987), pp. 1214. See also Clement Attlee, The Social Worker (London, 1920).

${ }^{99}$ Green, par. 205. 
sumption of rights." 100 A similar theory of punishment was presented by Bernard Bosanquet, except that he warned against the tendency in "reformation theory" to treat the offender "as a 'patient', not as an agent." ${ }^{101}$ In this manner, Bosanquet claimed, "it leads to the notion that the State may take hold of any man, whose life or ideas are thought capable of improvement, and set to work to ameliorate them by forcible treatment." ${ }^{102}$ In a later work, Bosanquet argued that "the reformatory theory, in its purity, is arbitrary and cruel," for "Revenge may be exhausted by a term in prison; it is the work of reformation to the duration of which no sane man can profess to set a limit." In words that have contemporary resonance, he asked rhetorically: "Could anything be conceived more brutalising, arbitrary, and oppressive? ... You want to annul the bad will, and in doing so, to help the offender against it so far as within reasonable limits you can. But to bind a man under the jurisdiction of some official expert in morals-say a gaol chaplain-till the latter should be satisfied of his reformation, would be a tyranny to which I find it hard to conceive a parallel." ${ }^{103}$ Punishment, in all, was " a negation of an evil will which has been realised in action"; "deterrence and reformation are subordinate aspects implied within it." 104 The correction of the young was a different matter, however, since it involved "imperfect wills, which have not entered upon complete responsibility.", 105

The import of all this is that the Idealist movement, a dominant intellectual force by the 1890 s, reinstated retribution as the key justification for punishment, with all that that entailed: individual responsibility, just proportion, and the quest for uniformity in sentencing. ${ }^{106}$ Moreover, the judiciary (which, strangely, Garland never includes within his "penal complex") was confirmed in its tendency to see the criminal law as an embodiment of the fundamental moral principles of the community and to guard against moves to limit their applicability. Attachment to classical notions of criminal justice was not a judicial peculiarity but was endemic among the prison service, even including prison doctors and psychiatrists. While top penal administrators were willing to accept that crimi-

${ }^{100}$ Ibid., par. 206. See H. B. Acton, The Philosophy of Punishment (London, 1969), p. 11; Paul Harris, "Moral Progress and Politics: The Theory of T. H. Green," Polity 21 (Spring 1989): 542. See also Henry Jones, The Working Faith of the Social Reformer (London, 1910), p. 254.

${ }^{101}$ B. Bosanquet, The Philosophical Theory of the State (London, 1910), p. 223.

102 Ibid., p. 224. in original.

${ }^{103}$ B. Bosanquet, Some Suggestions in Ethics (London, 1918), pp. 200-202, emphasis

104 Ibid., p. 207.

105 Ibid., p. 183.

${ }^{106}$ See Radzinowicz and Hood (n. 2 above), pp. 18-19. 
nality might have a physical basis in "degeneracy," particularly in "feeblemindedness," at the level of the prison medical officer continuity prevailed. Prison medical officers were preoccupied still with separating the malingerer from those who were unfit for prison discipline. Few of the "weakminded," however, were transferred elsewhere, even after 1913 and the Mental Deficiency Act, and a more thoroughgoing mental diagnosis and treatment of prisoners was a rarity. For the most part, medical officers continued to serve the "moral" mission of the prisons. ${ }^{107}$ But let us turn to the most powerful prison administrator, the chairman of the Prison Commission and devotee of T. H. Green, Evelyn RugglesBrise.

In explaining why this "humane and high-minded administrator, well versed in the literature of penology," a pillar of the International Penal and Penitentiary Commission, did so little to change the principles and practice of the prison regime in response to the Gladstone Report, Lionel Fox correctly highlighted Ruggles-Brise's own statements, "which suggest that he never really accepted the possibility of a system of treatment in which reform would hold a primary and concurrent place with deterrence." ${ }^{108}$ In an address to the American Prison Association in Washington in 1910, Ruggles-Brise argued forcefully against a change in the "historic order of the factors of punishment" - to wit, retributory, deterrent and, reformatory. For support, he turned to the formula "prescribed by one of the clearest and profoundest thinkers of the end of last century, Professor T. H. Green,' whose definitions Ruggles-Brise then emulated. By "retributory," said Ruggles-Brise, he meant "the determination of the human consciousness that the system of rights shall be maintained, and that he who offends against it shall be punished, and that the punishment shall be of such a nature as to deter him and others from anti-social acts." By "reformatory," he meant "the accepted axiom of modern penology that a prisoner has reversionary rights of humanity ... and that no effort must be spared to restore that man to society as a better and a wiser man and a good citizen." ${ }^{109}$ On other occasions, too, Ruggles-Brise warned against a retreat from the classical traditions of punishment. ${ }^{110}$

${ }^{107}$ See S. Watson, "Malingerers, the 'Weakminded' Criminal and the 'Moral Imbecile': How the English Prison Medical Officer Became an Expert in Mental Deficiency, 1880-1930," in Legal Medicine in History, ed. M. Clark and C. Crawford (Cambridge, 1994): 229; Hobhouse and Brockway (n. 47 above), pp. 257-85. See also Wiener (n. 23 above), p. 234; and Garland, "British Criminology before 1935" (n. 89 above), p. 5.

${ }^{108}$ Fox (n. 62 above), pp. 62-63.

${ }^{109}$ E. Ruggles-Brise, Prison Reform: At Home and Abroad (London, 1924), p. 193.

${ }^{110}$ See Report of the Commissioners of Prisons . . for 1912-1913, Cd. 7092, PP, 1914 , vol. 45 , pp. 22-23. 
Nothing, in Ruggles-Brise's opinion, had more retarded modern penology than the idea of a "criminal type," of persons predestined to crime. The idea challenged the entire system of punishment since the "criminal type" was hardly likely to be amenable to deterrent or reformatory influences. Fortunately, the tide of criminal anthropology ebbed quickly, as Ruggles-Brise recorded in 1910: "The Lombrosian theories of the criminal-né [sic] are exploded. Our own investigations now being conducted into the physiology of crime will, I think, fire the last shot at this deserted ship." "111 Ruggles-Brise had commissioned Dr. Charles Goring, medical officer at Parkhurst, to test Lombroso's theory by a largescale examination of English convicts. Happily, Goring successfully demolished the "physical criminal type." But ironically his finding that the English prisoner was, on average, defective, either physically or mentally, gladdened the heart of all eugenists. It required Ruggles-Brise, in his preface to The English Convict, to warn that Goring's "theory of defectiveness ... must not be pressed so far as to affect the liability to punishment of the offender for his act." ${ }^{112}$ Ruggles-Brise also contested other planks of the positivist credo. He rejected both an entirely indeterminate sentence and anything that trenched on judicial discretion in sentencing, "the most sacred principle of English Criminal Law." 113

Other features of the positivist paradigm attracted Ruggles-Brise. $\mathrm{He}$ endorsed the principle of "the individualization of punishment." 114 He recognized the merit of greater specialization in the treatment offered by each prison, adapted to different kinds of offender, ${ }^{115}$ apropos of which he recommended a special institution for mentally defective prisoners requiring long, possibly permanent detention. ${ }^{116}$ And he was generally supportive of preventive detention for habitual offenders. ${ }^{117}$ But RugglesBrise's most valuable contribution was surely the urge to save young adult offenders from a career of crime. Moreover, the development of

${ }^{111}$ E. Ruggles-Brise memo, April 18, 1910, PRO, HO 45/13658/185668/6.

${ }^{112}$ Charles Goring, The English Convict: A Statistical Study, abridged ed. (London, 1919), preface by E. Ruggles-Brise, p. vi. See Ruggles-Brise, English Prison System (n. 51 above), pp. 198-212. See also Radzinowicz and Hood, pp. 21-26; Wiener, p. 357; Piers Beirne, Inventing Criminology: Essays on the Rise of Homo Criminalis (New York, 1993), p. 213. Hobhouse and Brockway's English Prisons To-Day confirmed the view that the criminal type was manufactured by the prison system.

${ }^{113}$ Quoted in D. A. Thomas, Constraints on Judgment: The Search for Structured Discretion in Sentencing, 1860-1910 (Cambridge, 1979), p. 27. See Radzinowicz and Hood, p. 268, n. 17; E. Ruggles-Brise memo, July 13, 1910, PRO, HO 144/18869/ $196919 / 3$.

${ }^{114}$ Ruggles-Brise, Prison Reform, p. 195.

${ }^{115}$ Edward Marsh to W. Churchill, August 23, 1910, in Randolph Churchill, Winston S. Churchill: Companion Volume (Boston, 1969), 2, pt. 2:1196.

${ }^{116}$ E. Ruggles-Brise memo, April 9, 1910, PRO, HO 144/1085/193548/1.

${ }^{117}$ Radzinowicz and Hood (n. 2 above), pp. 269-71. 
the Borstal training system owed something to positivist criminology, more to American example, but much more to the social conscience of a follower of T. H. Green. Only for young, feebleminded, and gravely habitual offenders, those considered incapable of making moral choices, was Ruggles-Brise willing to waive the application of culpability, punishment, and moral reformation. He still saw the primary function of a humane administration to be "to secure obedience, discipline, order, and the habit of industry." "These things alone," he continued, "have a great moral value." 118

The Idealist movement thus influenced British legal circles and prison administration. Legal and jurisprudential thinking, reinforced by philosophical idealism, clung fast to the classical principles of moral culpability, responsibility, and of measure for measure between crime and punishment. Penal officials held tight to traditional modes of uniformly administered discipline and remained skeptical of, if also open-minded about, the positivist view of crime as the determined outcome of biological or environmental conditions. ${ }^{119}$ The upshot, I suggest, was a neoclassical philosophy and practice of punishment, by which I mean a continued legal appraisal of behavior in terms of moral choice, at least for sane adults (modified only by minor mitigating factors), and a departure from voluntarism with regard only to the young, the insane, and the feebleminded - in a word, those incapable of exercising free will-whose actions were largely determined. But determinist philosophies never came close to triumphing over older legal and penological imperatives. The Edwardian debate on prisons was guided less by the new positivist discourse and more by an Idealist framework of thought, with its stress on moral responsibility, just proportion, and the role of the state and citizens to secure the general protection of rights and to help the criminal resume the exercise of rights.

\section{VI}

The influence of "moral character," active citizenship, and the realization of the best possible self is evident, too, in ethical socialism. A

${ }^{118}$ Ruggles-Brise, English Prison System, p. 3. Ruggles-Brise was liverishly unsympathetic, therefore, to the Penal Reform League's 1918 complaints about degrading prison garb, "spy hole" practice, and the exclusion of outside news; see PRO, HO 45/11543/ 357055/9.

${ }^{119}$ See Forsythe, Penal Discipline, Reformatory Projects and the English Prison Commission, 1895-1939 (n. 26 above), p. 239; Garland, "British Criminology before 1935 ' (n. 89 above), p. 5. Idealism's influence might also explain, at least in part, the continued resort to voluntary agencies as an adjunct to the penal system, notably for discharged prisoners, probation, and Borstal aftercare. This feature of the penal system was of particular concern to Ruggles-Brise. 
fundamental strand of the ethical socialist tradition is a belief in the power of moral character both to improve individual conduct and to build a virtuous society. ${ }^{120}$ The important point, for present purposes, is that the moral fervor of ethical socialism contributed to the critique of Edwardian prisons by way of conscientious objection to participation in the First World War and the Prison System Enquiry Committee of the Labour Research Department.

Socialist war resisters, many from the ILP, made up three quarters of the membership of the No-Conscription Fellowship. They made common cause with Quaker Christians and libertarians, grouping around the principle of resistance to compulsion where life and death were concerned. ${ }^{121}$ Stephen Hobhouse, a Quaker pacifist (converted by Tolstoy's What I Believe) and long-time social worker in London's East End, observed later that the Quakers' faith "did not divide us in spirit from the many deeply sincere Socialists and others who were holding out against the army on grounds partly ethical and partly political." ${ }^{122}$ Hobhouse himself told the conscription tribunal in Shoreditch Town Hall that he chose conscientious objection "as a disciple of Jesus Christ and as an advocate of International Socialism." 123 The two main founders of the No-Conscription Fellowship, Fenner Brockway and Clifford Allen, were ILP socialists. Brockway edited the Labour Leader, the ILP's official journal. Allen, also a political journalist, opposed the "capitalist" war from the outset. In March 1916, requesting exemption from military service, he declared, "there is something of divinity in every human being, irrespective of the nation to which he belongs." As the war hastened the shift toward state power, Allen was attracted to guild socialism, defined by its defiance of the state. ${ }^{124}$ Robin Page Arnot, an ILP member, attempted

${ }^{120}$ For Idealism's influence on ethical socialism, see W. H. Greenleaf, The British Political Tradition (New York, 1983), 2:139; and Himmelfarb (n. 96 above), p. 261. See also N. Dennis and A. H. Halsey, English Ethical Socialism (Oxford, 1988), pp. 1-12.

${ }^{121}$ See Clifford Allen in Julian Bell, ed., We Did Not Fight (London, 1935), p. 28; T. C. Kennedy, The Hound of Conscience: A History of the No-Conscription Fellowship, 1914-1919 (Fayetteville, Ark., 1981), p. 48; Vellacott (n. 47 above), p. 29. See also Report of the Annual Conference of the I.L.P. (London, 1916), pp. 72-74. The treasurer of the No-Conscription Fellowship was Edward Grubb, a Quaker and former secretary of the Howard Association for Penal Reform.

${ }^{122}$ Leo Tolstoy, What I Believe (Geneva, 1888). S. Hobhouse's quote is in Bell, ed., p. 167. Hobhouse was from a wealthy Quaker family, but he renounced his inheritance of the family estate. For other details, see Hobhouse, Forty Years and an Epilogue (n. 49 above), pp. 174-77; A. G. Rose, "Some Influences on English Penal Reform, 1895-1921,"' Sociological Review 3 (July 1955): 34-37; Martin Ceadel, Pacifism in Britain, 1914-1945 (Oxford, 1980), p. 43.

${ }^{123} \mathrm{~S}$. Hobhouse in Bell, ed., p. 166.

${ }^{124}$ Quoted in Gilbert (n. 44 above), p. 5. See J. M. Winter, Socialism and the Challenge of War (London, 1974), p. 129. Bertrand Russell, chairman of the No-Conscription Fellowship during the final years of the war, also turned to guild socialism; see W. B. 
to evade conscription in May 1917 as a self-proclaimed revolutionary socialist; he served eighteen months in Wormwood Scrubs prison. ${ }^{125}$ A significant number of these conscientious objectors made up the next generation of penal reformers. Their first contribution was to the Labour Research Department's enquiry launched in 1919.

The Prison System Enquiry Committee was a heavily socialist outfit, although a number of socialisms were represented: ethical, Fabian, and guild. The chairman was Sydney Olivier, a Fabian socialist who sought a social reconstruction in accord with the highest moral possibilities. Committee members included George Bernard Shaw, the Webbs, and G. D. H. Cole, the guild socialist. ${ }^{126}$ Hobhouse and Brockway were, of course, the joint editors of the enquiry English Prisons To-Day, and they were assisted by Arthur Creech Jones, secretary of the Camberwell Trades and Labour Council, member of the Liberal Christian League, and also a conscientious objector. At times of greatest despair in prison, Creech Jones had been sustained by the faith "that humanity was one, that I was not a tool of the governing classes to slay my fellow workmen in a senseless, suicidal slaughter, that I was trying in a poor way to bear testimony to the ideals of liberty, internationalism, \& fraternity." 127

In summary, I would submit that another strand to the penal culture of these years was an ethical-cum-Christian socialism, a socialism that appealed to the common good, to social service, and to the power of moral character to perfect the person and to reform society. The overarching conclusions to this discussion of Edwardian penal culture seem inescapable. First, the set of attitudes to crime and punishment associated with the European positivist movement succumbed to the fatal embrace of British humanitarian, Idealism, and ethical thought. If positivism extended a superficial "scientific" allure to calls for penal reform, the bedrock sensibilities remained heavily "moral." Second, the different groups examined here assisted the continuing adherence to a more traditional jurisprudence and penality by the overlaps and relationships between their ideas and personnel. En bloc, these groups remained skeptical of the brave new world of positivist criminology and contributed to the widespread public disenchantment with the use of imprisonment.

Gwyn, "The Labour Party and the Threat of Bureaucracy," Political Studies 19 (December 1971): 385 .

${ }^{125}$ See H. E. Roberts, "Years of Struggle: The Life and Work of Robin Page Arnot," Labour History Review 59 (Autumn 1994): 58-63.

${ }^{126}$ N. MacKenzie and J. MacKenzie, The First Fabians (London, 1977), p. 62. See also Margaret Olivier, ed., Sydney Olivier: Letters and Selected Writings (London, 1948), chap. 3. The other committee members were penal reformers; see p. 308 above.

${ }^{127}$ Rhodes House Library, Arthur Creech Jones Papers, MS British Empire S 332, box 1, file 2, fol. 142: letter from Hounslow barracks, January 9, 1917. 


\section{VII}

Third, let me turn to what I conceive to be the significant development, not to say achievement, of the years 1895-1922: the reduction in the number passing through the prison turnstile. In evidence to the Gladstone Committee, Sir Godfrey Lushington, late permanent undersecretary at the Home Office, uttered the immortal lines: "I regard as unfavourable to reformation the status of a prisoner throughout his whole career; the crushing of self-respect; the starving of all moral instinct he may possess; the absence of all opportunity to do or receive a kindness; the continual association with none but criminals . . . the forced labour and the denial of all liberty. I believe the true mode of reforming a man or restoring him to society is exactly in the opposite direction of all these." ${ }^{128}$ Lushington's approach to criminal justice was shaped by a commitment to the classical Liberal ideal of the free and responsible individual. He was extremely skeptical of the reformatory claims of institutions and of the medicalization of criminal justice. The Gladstone Committee accepted the accuracy of Lushington's description but could not agree "that all of these unfavourable features are irremovable." 129 Nevertheless, the principal achievement of the years after Gladstone took place where Lushington pointed: outside prison. The main tendency of the period was not the expansion of preventive confinement, the emergence of new islands in the "carceral archipelago," but the extraordinary decrease in both the number of prisoners, especially those undergoing short sentences (and of the 200,000 committals to prison in 1909 , no fewer than 125,000 , or 61 percent, were under sentences of two weeks or less, over half of which were imposed on first offenders), ${ }^{130}$ and of the prison estate.

Detention in penal institutions was still the mainstay of the criminal justice system in the early twentieth century. The cardinal characteristic of the prison system was the enormous procession of persons sentenced for nonindictable (or less serious) offenses or those receiving sentences in default of payment of a fine for such offenses as drunkenness, minor assaults, or contravention of borough by-laws. In 1899, prison receptions

${ }^{128}$ Minutes of Evidence to the Departmental Committee on Prisons, C. 7702-I, PP, 1895, vol. 56, question 11482, p. 459. See J. Pellew, "Law and Order: Expertise and the Victorian Home Office," in Government and Expertise: Specialists, Administrators and Professionals, 1860-1919, ed. R. MacLeod (Cambridge, 1988), pp. 68-69. For a subtle and convincing assessment of Lushington's evidence to the Gladstone Committee, one that reveals that the permanent undersecretary defended the existing "punitive and deterrent" prison system yet faulted "the general spirit of administration," for which Du Cane was responsible, see McConville, English Local Prisons (n. 5 above), pp. 625-32.

${ }^{129}$ Report from the Departmental Committee on Prisons ( $\mathrm{n} .7$ above), p. 12.

${ }^{130}$ Victor Bailey, "Churchill as Home Secretary: Prison Reform,' History Today 35 (March 1985): 11. 
were running at 175,000 per annum, and the daily average population was about 14,500 in local prisons, 4,000 in the convict prisons. By 1903, receptions were close to 200,000 , and the daily average population rose to 20,000 . Thereafter, the numbers fell, but still in 1914 receptions numbered 150,000, and the daily average population stood at 18,000. Yet by 1918 , receptions had plummetted to 30,000 , and the daily average population was below 9,000. The prewar peaks were never again ascended. ${ }^{131}$ A number of factors explain this enormous decrease.

The Probation of Offenders Act, 1907, gave the courts another alternative to incarceration; the Children Act, 1908, excluded those aged under sixteen from prison. Of vital importance, the Criminal Justice Administration Act, 1914, did much to keep fine defaulters out of prison by allowing magistrates to give time for payment. Between 1910 and 1921, the numbers imprisoned annually for nonpayment of fines dropped from 85,000 to 15,000 . And the wartime combination of full employment and drinking restrictions resulted in a fall-off in the numbers imprisoned for minor offenses like drunkenness and vagrancy. The downward trend of the prison population, it should be stressed, was not the result of a decrease in crime but of the legislation mentioned above, the effect of war, and perhaps most crucially, of judicial willingness to move away from custody in their sentencing practice. ${ }^{132} \mathrm{~A}$ credible explanation of the judicial mindset would require separate investigation, but it is possible that justices were influenced by the disenchantment with prison that pervaded the press and the Home Office from the 1880s and by their own experience of the revolving doors of short-term imprisonment. In addition, home secretaries, aware of the effect that sentencing practice had on penal administration, were increasingly prepared to supervise magistrates and judges, either directly by circular or indirectly via the lord chancellor.

I am familiar, finally, with the fall-back position of the revisionist

${ }^{131}$ K. Neale, "Her Majesty's Commissioners, 1878-1978”' (Home Office, London, 1978, private circulation), pp. 19-20; E. H. Sutherland, "The Decreasing Prison Population of England,' Journal of Criminal Law and Criminology 24 (1933): 880-900. The figures specifically for women tell the same story. At the turn of the century, 50,000 women were annually committed to prison, largely for prostitution and drunkenness. In 1918 , commitments were 14,922 , a drop of 72 percent. The daily average in local prisons fell from about 3,000 to 1,500 prisoners. See E. Ruggles-Brise memo, October 22, 1918 , PRO, HO 45/11543/357055/9.

${ }_{132}$ For the figures cited, see Sidney Webb and Beatrice Webb, English Prisons under Local Government (1922; reprint, London, 1963), p. 248; Ruggles-Brise, English Prison System (n. 51 above), pp. 224-25; A. Rutherford, Prisons and the Process of Justice: The Reductionist Challenge (London, 1984), pp. 123, 130, and "Lessons from a Reductionist Era," in Robert and Emsley, eds. (n. 71 above), pp. 59-60. The rate of indictable crime recorded by the police rose by less than 10 percent between 1900 and 1921; see F. H. McClintock and N. H. Avison, Crime in England and Wales (London, 1968), pp. 18-24. 
historians, which is to insist that noncustodial measures actually extended the field of intervention available to the courts. Modern criminologists speak of the "hidden discipline"' of community corrections and suggest that it amounts to a qualitatively new and different pattern of penality. Perhaps so. For my part, I simply wish to insist that the revisionists' image of a prison system ingesting ever more prisoners into its insatiable maw is a gross exaggeration. We should be impressed rather with the prewar mood of profound skepticism about imprisonment, local and convict, a mood that one Liberal politician in particular helped to shape.

Winston Churchill, home secretary for an animated eighteen months in 1910-11, assisted the reductionist tendency. The first principle of prison reform, declared Churchill, "should be to prevent as many people as possible getting there at all. There is an injury to the individual, there is a loss to the State whenever a person is committed to prison for the first time." ${ }^{133}$ His opening gambit was audacious by the standards of any former or subsequent home secretary: "to arrange matters so that next year there will be 50,000 fewer people sent to prison than this year." 134 He not only wanted to reduce by one-third the annual committals to prison but also to reduce by $10-15$ percent the daily average prison population and to abolish all imprisonment for periods of less than one month. To reduce this "gigantic number of useless and often pernicious committals" 135 and avoid the unnecessary familiarization of offenders with prison surroundings, four main lines of advance were explored by Churchill.

First, for the 5,000 lads aged sixteen to twenty-one who were sent to prison each year for such offenses as gaming and stone throwing, Churchill proposed a system of "defaulters' drill," or physical exercise, to be administered at the police station. Second, there was to be time to pay fines. Third, imprisonment for debt was to be abolished. Finally, Churchill proposed a "suspensory sentence" of imprisonment for petty offenders. As a result, first or infrequent offenders would never go to prison for less than one month. ${ }^{136}$ Once the prisons were emptied of their deadweight of petty criminals, Churchill envisaged a radical reorganization of the penal system. The prison population was to be classified into twenty main categories and distributed for specialized treatment to "a

${ }^{133}$ Hansard Parliamentary Debates, 5th ser., vol. 19 (July 20, 1910), col. 1344.

${ }^{134}$ W. S. Blunt, My Diaries (New York, 1922), pt. 2, p. 335.

${ }^{135}$ W. Churchill minute, August 13, 1910, PRO, HO 144/18869/196919/1.

${ }^{136}$ Cabinet paper, "Abatement of Imprisonment," in R. Churchill (n. 115 above), 2, pt. 2:1198-1203; PRO, HO 45/10613/194534. For the full history of imprisonment for debt, see G. R. Rubin, "Law, Poverty and Imprisonment for Debt, 1869-1914," in Law, Economy and Society, 1750-1914: Essays in the History of English Law, ed. G. R. Rubin and D. Sugarman (Abingdon, 1984), pp. 241-99. 
regular series of scientifically graded institutions." ${ }^{137}$ Prisoners would be so distributed by a board of classification since no "scientific uniform system" could be administered through the courts. Churchill was in office too briefly to bring more than a few of his many planned reforms to fruition. Accordingly, his contribution to keeping people out of prison was characterized more by promise than accomplishment. Nonetheless, Churchill contributed to the mood of disenchantment with short-term confinement in "the general mixed prison," a mood that was rekindled in the postwar years by English Prisons To-Day. ${ }^{138}$

Churchill's tenure at the Home Office also serves to underscore a central ambivalence running through Edwardian Liberalism. The impulse toward scientific medicalization was continually balked by deep-rooted commitments to morality and liberty. This was noticeably evident in Churchill's approach to sentencing. Indeed, Churchill was more interested in the techniques of sentencing and commitment than in the administration of penal custody. His letters are far more concerned with who should or should not go to prison, and for how long, than what happened to them after they arrived. His thinking was dominated, moreover, by classical notions of justice, notably a just proportion between crime and penalty. He would have liked to set down a uniform scale of penalties for judges to follow. He had to make do with revising sentences piecemeal, searching the criminal calendars for cases of injustice, and exercising the prerogative of mercy to influence sentencing practice. ${ }^{139}$

Churchill was particularly disturbed by what he termed "the first fruits of the [Preventive Detention] Act": "It has greatly increased the severity of the criminal law, and the inequality of sentences," he wrote in June 1910. ${ }^{140}$ Through new administrative rules, Churchill sought to mitigate the inequalities arising from the working of the act and to restrict the act's scope to the criminal who was a "danger to society," whose newest crime was a serious offense. ${ }^{141}$ So, too, Churchill insisted that Borstal detention be reserved for those who had committed serious offenses, by which he meant rape, robbery with violence, and burglary. Some check must be imposed, he minuted, on the increasing tendency of the courts to inflict sentences of three years' imprisonment at Borstal

${ }^{137}$ PRO, HO 144/18869/196919/1.

${ }^{138}$ See also Webb and Webb, p. 248. And see Robert Badinter, La prison républicaine (1871-1914) (Paris, 1992): the penal reforms introduced in France (suspended sentence, conditional release, educational solutions for juveniles) all had as their aim the avoidance of the prison, not its reformation.

${ }^{139}$ See Radzinowicz and Hood (n. 2 above), pp. 770, 773; Addison (n. 38 above), pp. 112-17; Thomas (n. 113 above), pp. 40, 46-47.

${ }^{140}$ PRO, HO 45/10589/184160/23.

${ }^{141}$ Ibid., 184160/25a. See also Thomas, pp. 41-45; Addison, pp. 118-19. 
for offenses that would ordinarily receive six months or less. And linking both provisions of the Prevention of Crime Act, 1908, together, Churchill wrote: "Within proper limits both the Borstal and Preventive Detention systems are desirable as being beneficial and humane refinements upon the ordinary prison system. Beyond those limits they cannot be defended and will quickly draw upon themselves a current of public displeasure. I should certainly not consent to be responsible for any system which can be shown to aggravate the severity of the Penal Codes." ${ }_{142}$

Churchill was ready to sanction prolonged detention (of up to two years) in curative labor colonies for habitual offenders convicted repeatedly of vagrancy and drunkenness, and he inclined to the eugenic in proposals to deal with the feebleminded. ${ }^{143}$ This could be expected of a young politician who had donned the coat of the New Liberalism in all its progressive and welfarist colors. The influence of positivist criminology was never such, however, as to shake Churchill's dependence on the classical principles of deterrence, just proportion, and uniformity of treatment. In the face of "scientific reform," he displayed a meticulous regard for what he termed "the rights of convicted criminals against the State." " 144 He resisted the advance of indeterminate detention, the emblem of the new penology, except with regard to the segregation of mental defectives. ${ }^{145}$ And he curbed the excesses, as he saw them, of the semiindeterminate sentences of preventive detention and Borstal training.

\section{VIII}

The debate on English prisons between 1895 and 1922 was framed by the unchanging structures of a harsh prison system and the related determination to diminish the number of persons passing through prison gates. Despite the good intentions of the Gladstone Committee, the pace of progress in humanizing prisons was glacial. The prison discipline meted out to conscientious objectors during the war was almost identical to that suffered by Oscar Wilde, a quarter century before: "Deprived of books, of all human intercourse, isolated from every humane and hu-

${ }^{142}$ PRO, HO 144/18869/196919/2.

${ }^{143}$ See PRO, HO 144/A60866/4; HO 45/10520/138276/57; Radzinowicz and Hood, pp. 372-75; Addison, pp. 123-26; Searle (n. 74 above), pp. 107-8. According to his friend, William Scawen Blunt, Churchill was "a strong eugenist"; see Blunt, p. 399 (entry for October 20,1912). When the Cabinet discussed the issue of "the unfit" in December 1911, Churchill presented Dr. A. F. Tredgold's article, "The Feeble-Mindeda Social Danger," which warned of the peril of "national degeneracy." See Ted Morgan, Churchill: Young Man in a Hurry, 1874-1915 (New York, 1982), p. 289.

${ }^{144}$ Hansard Parliamentary Debates, 5th ser., vol. 19 (July 20, 1910), col. 1354.

${ }^{145}$ PRO, HO 45/1085/193548/1. 
manising influence, condemned to eternal silence, robbed of all intercourse with the external world, treated like an unintelligent animal, brutalised below the level of any of the brute-creation, the wretched man who is confined in an English prison can hardly escape becoming insane." ${ }^{146}$ Is this Oscar Wilde or Hobhouse and Brockway? It hardly matters, since it could serve as an accurate description of the prison regime both in 1895 and 1921 . The special measures proposed by the Gladstone Committee met with no greater success than the attempts to improve prison conditions. If Borstal training was lauded as a progressive step in the treatment of young adult offenders, the various forms of preventive detention for habituals, defectives, inebriates, and vagrants met with considerable judicial, administrative, and public skepticism, so much so that all withered on the vine. To see all this as a new penal structure, as an integral part of a "modern penal complex," seems terribly wide of the mark.

Nor is it any more convincing to see positivism as the main ideological inspiration of the limited changes that did take place. Judges, prison administrators, and penal reformers were generally familiar with the ideas of individualization, classification, and indeterminacy, but true converts were thin on the ground, and their ranks became thinner as the first flush of enthusiasm dissipated. The new scientific knowledges, whether Lombrosian positivism or British eugenics, far from being incorporated into penal practice, were held at arm's length. Judges and prison officials remained loyal to the classical credo of moral culpability, a just measure of punishment, and uniformly administered discipline. In this they were guided by a jurisprudence and a civic consciousness that drew inspiration from philosophic idealism. Lombrosian criminal man was born, his action the determined outcome of biological inheritance, his fate to be incarcerated in perpetuity to protect society against his dangerousness. By contrast, Idealist criminal man was a responsible agent, his action the willed violation of an explicit social right, his fate to have his bad will annulled by a punishment proportionate to the importance of the right violated. As such, the prisoner possessed an individual human worth, and the state had the duty to safeguard his "reversionary rights" by sending him out better fitted to assume the role of citizen. This philosophy shaped the idée fixe of a host of administrators, reformers, and social workers in the early twentieth century, and, as I have argued elsewhere, was the predominant influence on the patterns of criminal policy and practice in the $1920 \mathrm{~s}$ and $1930 \mathrm{~s} .{ }^{147}$

${ }^{146}$ Wilde, The Soul of Man (n. 10 above), p. 193.

${ }^{147}$ Bailey, Delinquency and Citizenship (n. 59 above). 
If there was a sea change in prison policy and practice between 1895 and 1922, then it was surely the massive reduction in the number of short-sentence prisoners. The tightening of urban regulations in the nineteenth century had brought growing numbers of citizens into conflict with the law through drunkenness and street offenses and growing numbers into the prisons, either directly or in default of fine payment. In their campaigns to make inroads into this mass of petty imprisonments, the reformers were aided by the prewar Liberal home secretaries, Herbert Gladstone and Winston Churchill, by a war that for various reasons reduced the size of the social "residuum" from which much of the shortstay prison population was drawn, and by a change in judicial sentencing practice about which we still know too little. From the vantage point of the present day, when the number of prisoners continues to rise inexorably, the steep drop in both prison receptions and daily average population in the first quarter of this century is remarkable. It was this statistical change, based in turn on a change in the judicial, prison, and political temper, on which Sidney and Beatrice Webb concluded their historical study of the administration of English prisons, published simultaneously with Hobhouse and Brockway's English Prisons To-Day. Echoing Sir Godfrey Lushington's evidence to the Gladstone Committee, the Webbs wrote:

The reflection emerges that, when all is said and done, it is probably quite impossible to make a good job of the deliberate incarceration of a human being in the most enlightened of dungeons. Even the mere sense of confinement, the mere deprivation of liberty, the mere interference with selfinitiative - if in any actual prison the adverse regimen were, in practice, ever limited to these restrictions - could hardly ever, in themselves, have a beneficial result on intellect, emotions or character. We suspect that it passes the wit of man to contrive a prison which shall not be gravely injurious to the minds of the vast majority of the prisoners, if not also to their bodies. So far as can be seen at present, the most practical and the most hopeful of "prison reforms" is to keep people out of prison altogether! ${ }^{148}$

${ }^{148}$ Webb and Webb (n. 132 above), pp. 247-48. 